\title{
TLRs, future potential therapeutic targets for RA
}

Hatem A. Elshabrawy ${ }^{\text {a,b }}$, Abdul E. Essani ${ }^{\text {a,b }}$, Zoltán Szekanecz ${ }^{c}$ David A. Fox ${ }^{\text {d }}$ and Shiva Shahrara ${ }^{\mathrm{a}, \mathrm{b} *}$

${ }^{\mathrm{a}}$ Division of Rheumatology, Jesse Brown VA, Medical Center, Chicago, IL 60612; USA.

${ }^{b}$ Department of Medicine, Division of Rheumatology, University of Illinois at Chicago, IL 60612; USA.

${ }^{c}$ Department of Rheumatology, Institute of Medicine, University of Debrecen Faculty of Medicine, Nagyerdei Str 98, Debrecen, H-4004; Hungary.

${ }^{\mathrm{d}}$ Division of Rheumatology and Clinical Autoimmunity Center of Excellence, University of Michigan, Ann Arbor, MI 48109; USA

*Address correspondence to: Shiva Shahrara Ph.D., University of Illinois at Chicago, Department of Medicine, Division of Rheumatology, MSB 835 S Wolcott Ave., E807E809, Chicago, IL 60612, Telephone: 312-413-7529, Fax: (312) 413- 9271, E-mail: shahrara@uic.edu

Key words: Rheumatoid arthritis (RA), toll like receptors (TLR)s, inflammation, bone erosion, M1 macrophages and TH-17 cells 


\begin{abstract}
Toll like receptor (TLR)s have a central role in regulating innate immunity and in the last decade studies have begun to reveal their significance in potentiating autoimmune diseases such as rheumatoid arthritis (RA). Earlier investigations have highlighted the importance of TLR2 and TLR4 function in RA pathogenesis. In this review, we discuss the newer data that indicate roles for TLR5 and TLR7 in RA and its preclinical models. We evaluate the pathogenicity of TLRs in RA myeloid cells, synovial tissue fibroblasts, $\mathrm{T}$ cells, osteoclast progenitor cells and endothelial cells. These observations establish that ligation of TLRs can transform RA myeloid cells into M1 macrophages and that the inflammatory factors secreted from M1 and RA synovial tissue fibroblasts participate in TH-17 cell development. From the investigations conducted in RA preclinical models, we conclude that TLR-mediated inflammation can result in osteoclastic bone erosion by interconnecting the myeloid and $\mathrm{TH}-17$ cell response to joint vascularization. In light of emerging unique aspects of TLR function, we summarize the novel approaches that are being tested to impair TLR activation in RA patients.
\end{abstract}




\section{INTRODUCTION}

Prevalent in $1 \%$ of the population, rheumatoid arthritis (RA) is one of the most common autoimmune disorders [1]. RA is characterized by persistent inflammation driven by the proliferating synovial tissue fibroblasts as well as $\mathrm{T}$ and $\mathrm{B}$ cells, neutrophils and monocytes trafficking into the joint $[2,3]$. Cells invading the RA pannus express proinflammatory cytokines, chemokines and matrix metalloproteinases that contribute to progressive cartilage and bone destruction [3-5].

The etiopathology of RA is not fully defined; however several genetic and environmental factors have been implicated [6]. Genetic loci associated with RA susceptibility include HLA-DR4, PTPN22, PADI4, STAT4, CTLA4, TNF, IL-1 and IL-18. The major environmental factor that augments risk for and severity of RA is smoking, especially in HLA-DRB1 patients, with possible additional roles for infection and tissue injury. Toll like receptors (TLR)s are the front line sensors of danger signals that are released following injury or infection, and by pathogens [7] (Fig. 1).

The functions of TLR2 and TLR4 have been extensively studied in RA through use of in vitro systems and experimental models [8-11], however more recent studies have also revealed a significant impact of TLR5 and TLR7 in RA pathology [12-16]. Depending on localization and distribution patterns of TLRs and their associated signaling pathways in RA patients, various TLR family members are important in different stages of disease [811]. Herein, we review the most recent advances concerning the importance of TLR function in RA with a specific focus on TLR5 and TLR7 in RA and in animal models of 
RA. Furthermore, we summarize potential therapeutic approaches targeting TLRs, their endogenous ligands and the signaling pathways associated with these receptors (Fig. 2).

\section{TLR expression pattern, their corresponding exogenous and endogenous ligands as well as TLR association with RA pathology}

TLRs represent a family of pattern recognition receptors and to date 10 subtypes have been identified in human (TLR1-10) and 12 in mouse (TLR1-9, TLR11-13). TLRs are classified based on their cellular localization and ligand selection. TLRs 1, 2, 4, 5 and 6 are expressed on the cell surface and recognize microbial components, whereas, endosomal TLRs 3, 7, 8 and 9 mainly detect nucleic acids [17] (Fig. 2 and Table 1).

\section{Cell surface TLRs}

\subsection{TLR1}

TLR1 is anchored in the plasma membrane and it predominately forms a heterodimer with TLR2 (Fig. 2). The TLR1/TLR2 complex recognizes tri-acetylated lipopeptides coupled to peptidoglycan (PGN) [18]. TLR1 is expressed on leukocytes such as monocytes, macrophages, $\mathrm{B}$ and $\mathrm{T}$ cells, dendritic cells (DC)s, NK cells, polymorphonuclear cells (PMN)s as well as non-immune cells including RA fibroblasts, keratinocytes and epithelial cells [19].

\subsection{TLR2 and TLR4}


TLR2 recognizes a wide range of ligands through heterodimers that it forms with TLR1 and TLR6 [20], and possibly TLR10 (Fig. 2). In contrast, TLR4 typically binds to its corresponding ligand as a homodimer, although in some exceptional cases TLR4 forms a dimer with TLR5 [21, 22]. Several Pathogen-Associated Molecular Patterns (PAMPs), such as lipoarabinomannan (LAM), LPS, lipoteichoic acid (LTA), PGN, and other glycolipids, glycoproteins, and lipoproteins, are activators of TLR2 [23-27]. Moreover, TLR2 heterodimers are recognized by viral envelope proteins of measles virus (MV), human cytomegalovirus (HCMV), herpes simplex virus type 1 (HSV1) and hepatitis C virus (HCV), fungal zymosan and some protozoa [25, 28-30]. However, TLR4 is activated by LPS, as well as fungal mannan and glucuronoxylmannan [30]. Furthermore, the TLR4 dimer can be activated by envelope proteins of respiratory syncytial virus (RSV), HCV, and mouse mammary tumor virus (MMTV)[30]. In addition, damageassociated molecular patterns (DAMPs) activate TLR2 and TLR4 signaling. Heat shock protein (HSP) 60 and 70, biglycan, GP96, high mobility group box (HMGB)1, Surfactant protein $\mathrm{A} / \mathrm{D}$ and HA fragments are endogenous ligands that are capable of TLR2 and TLR4 ligation [31-36]. Recent studies demonstrate that DAMPs utilize unique combination of co-receptors and accessory proteins, therefore TLR activation and function may vary depending on DAMP or PAMP binding.

In line with elevated levels of endogenous ligands, TLR2 and TLR4 are highly expressed by RA synovial tissue (ST) lining macrophages and fibroblasts and sublining macrophages [36, 37]. In vitro studies confirmed the expression of TLR2 and TLR4 on RA peripheral blood (PB) monocytes, macrophages differentiated from PB and synovial 
fluid (SF) monocytes and RA ST fibroblasts [36-38]. Although, TLR2 and TLR4 function has been implicated in RA pathogenesis, there is conflicting information regarding association of single nucleotide polymorphisms (SNP)s of TLR2 and TLR4 with severity of RA $[39,40]$.

\subsection{TLR5}

Prior to 2012, very little was known about the role of TLR5 in RA. TLR5 binds as a monomer to flagellin and recent studies document that TLR5 endogenous ligands are present in RA SF [12-14], although the identity of these natural ligands remain unknown. TLR5 expression is accentuated in RA compared to normal (NL) lining fibroblasts and macrophages and sublining macrophages and endothelial cells [14]. In RA PB monocytes and in vitro differentiated macrophages expression levels of TLR5 are increased by TNF and IL-17 respectively; whereas various monokines and RA SF can upregulate TLR5 on RA ST fibroblasts [14]. Notably, myeloid TLR5 expression positively correlates with RA disease activity (DAS28) and with TNF levels, supporting its role in RA pathology [14].

\subsection{TLR6}

TLR6 heterodimerizes with TLR2, and hence binds to the same exogenous ligands and some of the TLR2 endogenous ligands [11,20]. Although TLR1, TLR2 and TLR6 have similar expression patterns, expression of TLR1 and TLR6 is more prominent than TLR2 on B cells [41]. Nevertheless, the impact of TLR6 is undefined in RA. 


\section{Endosomal TLRs}

\subsection{TLR3}

TLR3 is different from the other family members, as it does not signal via MyD88, but instead exclusively activates TIR-domain-containing adapter-inducing interferon- $\beta$ (TRIF) [42, 43]. The expression of TLR3 was determined, by some groups, to be restricted to DCs, however others reported that TLR3 is expressed by T cells, NK cells, granulocytes and monocytes [44-46]. TLR3 forms a homodimer and is activated by viral double stranded (ds) RNA which suggests that the dsRNA released from necrotic cells in the RA SF is the TLR3 endogenous ligand [47]. Previous studies showed that a TLR3 (rs3775291) SNP is associated with DAS28 and swollen joint counts in the Danish seronegative RA population [48]. In contrast, no correlation was detected between the TLR3 (rs3775290) SNP and RA susceptibility factor in the Turkish population [49]. In RA synovial tissue (ST), joint fibroblasts express elevated levels of TLR3 at the early stage of disease [34]. Others demonstrate that TLR3 is equally expressed by RA and NL monocytes, and interferon (IFN) $\alpha$ is capable of elevating TLR3 expression levels on both RA myeloid cells and ST fibroblasts [50, 51]. Supporting this notion, the expression patterns of TLR3 and IFN $\alpha$ are closely correlated in RA ST $[50,51]$. When RA and NL myeloid cells were stimulated by a TLR3 agonist, the inflammatory response was similar in both healthy and RA cells [51]. Altogether, the literature suggests that the pathogenic effect of TLR3 is due to its differential expression in RA compared to NL fibroblasts and its presence on myeloid cells is less significant for disease progression. 


\subsection{TLR7 and TLR8}

Both TLR7 and TLR8 recognize ssRNA [16], however recent findings document that these receptors bind to specific RNA sequences [15]. While TLR7 binds to GU-rich oligos, TLR8 tends to ligate to AU-rich domain $[52,53]$. Corroborating these findings, we showed that although both TLR7/8 can recognize ssRNA extracted from RA SF [16], the GU-rich micro RNA (miR)-Let7b released from RA SF macrophages has a unique ability to bind to TLR7 and is not recognized by TLR8 [15]. It was demonstrated that RNA from RA SF, but not RA or NL plasma, could induce TNF transcription from RA monocytes. Consistently, inhibition of myeloid TLR7 ligation or degradation of ssRNA suppresses SF induced TNF transcription, establishing that TLR7 endogenous ligands are enriched in RA SF [16]. Both in RA blood and SF, miR-Let7b is primarily released from macrophages and it is secreted at lower levels from blood $\mathrm{T}$ cells and neutrophils as well as from RA ST fibroblasts [15]. To date, the TLR8 endogenous ligand has not been identified.

TLR7 and TLR8 are predominately expressed by RA ST lining and sublining macrophages as well as by RA ST lining fibroblasts [16]. Nevertheless, their expression is differentially regulated in RA myeloid cells [16]. While expression of TLR7 is enhanced by IL-17 and IL-8; LPS and IL-1 are responsible for increasing the TLR8 levels in RA monocytes and macrophages [16]. Interestingly, expression of TLR7 in RA monocytes correlates with DAS28 and TNF levels. By contrast, expression of TLR8 in RA myeloid cells does not correlate with DAS28, TLR7 or TNF levels [15]. 


\subsection{TLR9}

TLR9 recognizes internalized bacterial DNA and non-methylated CpG oligonucleotides $[54,55]$. Ribosomal DNA containing non-methylated $\mathrm{CpG}$ repeats, released from the dead cells in the RA serum, can potentially be a TLR9 endogenous ligand [54, 55]. TLR9 is expressed by B cells and it operates synergistically with the B cell receptor complex to release rheumatoid factor (RF) [56]. Additionally, ligation of TLR9 by CpG promotes B cell class switch from IgM to a more pathogenic IgG isotype [57]. TLR9 is elevated in RA compared to osteoarthritis (OA) ST fibroblasts and its expression is augmented by hypoxia in RA ST fibroblasts [58]. Moreover, RA patients with active disease expressed markedly higher levels of TLR9 in PB monocytes and SF macrophages compared to NL counterpart cells [59]. A correlation was found between a TLR9 (rs187084) SNP and RA susceptibility in the Turkish population [49].

\subsection{TLR10}

TLR10 is expressed on human but not in murine immune cells, with the highest levels in B cells $[41,44]$. TLR10 forms a heterodimer with TLR2 and is therefore responsive to TLR2-binding PAMPs $[23,26]$. Little is known about TLR10 endogenous ligands and function, but a recent study reported that TLR10 is induced following influenza virus infection and it may play a role in the innate immune responses to the influenza virus [60]. In contrast, others found that TLR10 may serve as an anti-inflammatory receptor by reducing proinflammatory cytokine production by human PBMCs [61]. Consistent with the previous findings, TLR10 knockdown elevated cytokine release from human myeloid 
cells. Correspondingly, mice overexpressing human TLR10 demonstrated a significantly lower inflammatory response when injected with the TLR2 ligand, Pam3CSK4 [61].

Taken together, RA macrophages and ST fibroblasts are the effector cells that play an integral role in TLR-mediated inflammatory mechanisms that are relevant to arthritis. In subsequent sections, we will review the mechanisms by which TLR ligation impacts RA synovial lining cells as well as the other cell types that are involved in the pathogenesis of RA.

\section{Mechanisms of TLR function}

Biological agents that have been approved for RA therapy include antibodies that target TNF or IL-6 activity as well as therapeutics that block T cell function or deplete B cells. Yet, there are subsets of RA patients that do not respond to the aforementioned strategies. Therefore the need persists for novel therapeutic approaches that are more effective and less expensive. To understand the significant importance of TLR function in RA, we focus on RA cells that highly express these receptors and are therefore responsive to their corresponding exogenous and endogenous ligands. We will also discuss the cells that are indirectly impacted by TLR activation in the RA joint.

2.1 Macrophages: Monocytes migrate from blood into the inflamed RA joint where they differentiate into macrophages. Macrophages are categorized into M1 and M2 subsets. M1 macrophages are the classically activated cells that produce proinflammatory cytokines, which mediate resistance to pathogens and provoke tissue damage. M2 
macrophages are the alternatively activated cells which secrete anti-inflammatory factors participating in tissue restoration [62, 63]. As previously described, TLR2, TLR4, TLR5, TLR7 and TLR8 are highly expressed by RA PB monocytes, ST and SF macrophages, and ligation by their exogenous and endogenous ligands promotes inflammatory response $[11,35,37,64]$.

\subsubsection{TLR2 and TLR4}

In RA monocytes and ST macrophages, TLR2 expression levels were elevated by macrophage colony stimulating factor (M-CSF) and IL-10 treatment [37]. In contrast, while IL-10 had no effect on myeloid TLR4 concentration, transforming growth factor (TGF)-1 had a suppressive effect on TLR4 levels [65]. Others have shown that the M1 driving factor, IFN- $\gamma$, increases monocyte response to LPS by upregulating TLR4 surface expression [66]. Interestingly, sex hormones have a differential impact on TLR4 levels. Estrogen upregulates myeloid cell surface TLR4 expression, whilst testosterone reduces the receptor level on macrophages $[67,68]$.

Earlier studies demonstrated that RA PB and SF myeloid cells are responsive to TLR2 and TLR4 microbial ligands. More recent studies determined that HSP60 and GP96 binding to TLR2 and/or TLR4 can elicit similar inflammatory response [37, 69]. On the contrary, release of miR-155 from macrophages during inflammation can restrict the secretion of inflammatory cytokines during the late phase of TLR4 ligation in these cells [70]. Notably, in NL PB in vitro differentiated macrophages and RA SF macrophages, GP96 stimulation markedly accentuates TLR2 expression, while this natural ligand has 
an inverse effect on TLR4 levels in NL PB myeloid cells [10, 69], suggesting that TLR2 and TLR4 are differentially modulated in myeloid cells.

\subsubsection{TLR5}

We have shown that ligation of exogenous as well as endogenous TLR5 ligands expressed in RA SF can transform naive RA myeloid cells into proinflammatory M1 macrophages [14]. Additionally, TNF produced from M1 macrophages can synergize with the TLR5 agonist, flagellin, to promote monocyte chemotaxis [12]. Consistently, blockade of TLR5 on myeloid cells and neutralization of TNF in RA SF can more potently suppress RA SF driven monocyte infiltration compared to inhibition of each cascade alone [14]. We further document a cross talk between TLR5 and TNF pathways, as patients on the combination of disease-modifying anti-rheumatic drugs (DMARD)s and anti-TNF antibody treatment demonstrated markedly lower myeloid TLR5 expression compared to those treated only with DMARDs [14].

\subsubsection{TLR7 and TLR8}

Binding of the TLR7 and TLR8 agonist, R848, to RA monocytes and macrophages induces TNF and CCL21 production [16]. Interestingly, it is shown while expression of TLR7 closely associates with TNF transcription levels in RA monocytes, the concentration of TLR8 does not correspond to TLR7 or TNF expression [16]. The SF ssRNA that binds to RA TLR7+ myeloid cells, is a GUUGUGU rich miR-Let7b that is predominately packaged in exosomes of RA SF macrophages [15]. Knockdown of TLR7 
but not TLR8 suppressed the miR-Let7b-mediated inflammatory response in myeloid cells [15]. Induction of cell death in RA SF macrophages can further amplify the discharge of the exosomal miR-Let7b into the SF [15]. Similar to the M1 macrophage positive controls, IFN $\gamma$ and LPS, miR-Let7b can remodel the RA naïve myeloid cell into M1 macrophages that express elevated levels of iNOS and CD127 [15]. The M1 differentiation process is driven by miR-Let7b through TLR7 ligation, given that the use of TLR7 antagonists or TLR7 knockout mice impairs this process [15]. Consistent with this notion, we reported that exosomes containing miR-Let7b are fully functional and can transform mouse naïve (M0) or anti-inflammatory (M2) macrophages into inflammatory M1 macrophages [15].

In short, evidence from our lab and other groups, highlights that ligation of myeloid TLR2, TLR4, TLR5 and TLR7 by their natural ligands expressed in RA SF can remodel naïve cells into proinflammatory M1 macrophages.

2.2 RA ST fibroblasts: The hyperplastic RA lining layer consists of RA fibroblasts and macrophages which expand from 1-3 layers to 10-15 cell layers in the inflamed joints [71]. Neovascularization of RA synovium triggered by pro-angiogenic growth factors released from fibroblasts can further potentiate inflammation via increased leukocyte infiltration $[63,72]$. It is known that fibroblasts within the RA hyperplastic ST overgrow the underlying cartilage surface and subsequently invade cartilage and bone to promote joint destruction $[71,73]$. Factors secreted into RA SF as a result of joint destruction or cell death can serve as TLR natural ligands. 
TLR2, TLR3, TLR4, TLR5, TLR7 and TLR9 are expressed by RA ST fibroblasts. TLR2 expression on RA ST fibroblasts is modulated by TNF, IL-1, LPS and miR-19 [34, 35, 37, 74-77]. While IL-17 upregulates expression of TLR2, TLR3 and TLR4 on RA ST fibroblasts [78], proinflammatory factors such as TNF- $\alpha$, IL-1 $\beta$, IL-17, IL-6, IL-8 and RA SF could greatly elevate TLR5 expression in RA fibroblasts [14]. Despite the higher expression of TLR7 in RA compared to NL fibroblasts, unlike TLR5, its expression was not affected when cells were stimulated with LPS, TNF- $\alpha$, IL-1 $\beta$, IL-17, IL-6, IL-8 or RA SF [16]. Unlike TLR7, expression of TLR8 was undetectable in RA or NL ST fibroblasts [16]. Low levels of TLR9 were detected in RA ST fibroblasts which were not inducible by activation with CpG ODNs $[58,79]$.

TLR2 ligation in RA ST fibroblasts enhances secretion of proinflammatory cytokines (IL-6, CCL8), proangiogenic factors (VEGF, IL-8, CXCL2) adhesion molecules (ICAM1) and matrix metalloproteinases (MMPs1/3/13) [37]. In RA ST fibroblasts, TLR2 and TLR4 ligation can synergistically contribute to IL-15 production [74]. Hypoxia potentiates TLR2-, TLR3- and TLR9-driven IL-6 and IL-8 transcription from RA ST fibroblasts. In contrast, TLR4-induced IL-6 and IL-8 expression is suppressed by hypoxia in these cells [58]. IL-29 also accentuates TLR2, TLR3 and TLR4 mediated IL-6 and IL8 production from RA ST fibroblasts [80]. Moreover, receptor activator for nuclear factor $\kappa \mathrm{B}$ ligand (RANKL), MMP1 and MMP2 were released from TLR2, TLR3 and TLR4 activated RA ST fibroblasts [81]. Binding of synthetic TLR3 ligand as well as stimulation with necrotic SF cells promotes production of IFN- $\beta$ from RA ST fibroblasts which is 
known to impair osteoclast differentiation [47]. Ligation of TLR5 by flagellin can dose responsively secrete IL-6 and CCL2 from RA ST fibroblasts [14].

In the RA pannus, fibroblasts are in direct contact with macrophages, $\mathrm{T}$ cells and vascular endothelial cells. Consequently, factors produced from fibroblasts under stress, hypoxia or inflammation can trigger further pathological changes in these neighboring cells.

2.3 Osteoclast maturation: Osteoclasts are multinucleated bone-eroding cells that differentiate from the myeloid cells found in RA PB or ST. RA joint macrophages cultured in presence of inflammatory cytokines or RA SF differentiate into mature osteoclasts. Osteoclast formation is mediated through ligation of myeloid receptor activator for nuclear factor $\mathrm{\kappa B}$ (RANK) to its ligand, RANKL, produced from RA ST fibroblasts and T cells $[2,82-85]$.

\subsubsection{TLR2, 3, 4 and 9}

Earlier studies demonstrate that TLR2 and TLR4 exogenous ligands cooperate with IFN$\gamma$ in suppressing RANK and M-CSR receptor expression, thus impairing osteoclast maturation [86]. Others observed that ligands for TLR2, 3, 4 and 9 had an inhibitory effect on osteoclast differentiation by reducing the production of RANKL [87]. A different study documented that osteoclastogenesis is impaired by IL-12 produced from TLR9 stimulated osteoclast precursor cells [88]. Despite the inhibitory effect of TLR2 and TLR4 on osteoclastogenesis, once osteoclasts are formed, ligation of TLR2 and 
TLR4 enhances the survival of the differentiated cells [87]. In contrast to in vitro studies, results from experimental arthritis models support a role of TLR4 in arthritic bone destruction $[89,90]$.

\subsubsection{TLR5}

The TLR5 agonist, flagellin, dose-dependently promotes osteoclast maturation, both through its direct effect on myeloid cell function and indirectly via TNF production from RA and mouse myeloid cells $[12,14]$. Consistent with findings in RA, TLR5 ligation strongly transforms mouse bone marrow progenitor cells into mature osteoclasts through a TNF-dependent and IFN- $\beta$-independent mechanism [12]. A potent positive feedback regulation has been described between TLR5 and TNF cascades in recruiting circulating monocytes into the inflamed joints and further remodeling the newly infiltrated cells into mature osteoclasts [12].

\subsubsection{TLR7/8}

The TLR7- and TLR8-binding oligo, R848, was shown to dose responsively negate RANKL induced osteoclast differentiation in NL PB myeloid cells as well as in mouse bone marrow progenitor cells through a mechanism that was partially due to IFN$\beta$ induction [91]. However, once mouse bone marrow osteoclasts were fully matured, R848 treatment had no impact on osteoclast survival or their bone-resorbing activity [91]. The data from the literature suggests that TLR ligands can differentially impact RA osteoclastic bone erosion and their maintenance depending on the osteoclast maturation stage. 
2.4 $\mathrm{T}$ cell function: We and others have shown that there is a dominance of $\mathrm{TH}-17$ cells in RA PB and SF compared to normal individuals [92-95]. In RA patients, the balance between TH-17 cells and $\mathrm{T}$ regulatory cells $\mathrm{T}(\mathrm{reg}) \mathrm{s}$ is dysregulated and Tregs have reduced suppressive activity $[96,97]$. TLRs are known to have an integral role in T cell differentiation and function.

Previous studies reported that conditioned media obtained from human PBMCs stimulated with TLR4 and TLR7/8 agonists, but not from those activated with TLR2, 3 and 9 agonists, promoted TH-17 cell differentiation [98] (Fig. 3). Interestingly, binding of myeloid related protein (MRP)8 expressed in RA SF to TLR4 in PBMCs induces TH-17 polarization $[99,100]$. Consistently, IL-6 produced from RA ST fibroblasts, activated by MRP8, was capable of transforming naïve CD4+ T cells into TH-17 cells [101] (Fig. 3). Others have shown that activation of TLR4 and TLR9 but not TLR2, in B and T cell cocultures markedly increases expression of retinoic acid related orphan receptor (RORC) and IL-17 [102]. Confirming this notion, it was shown that the Treg cell population was reduced in TLR2-/- compared to wild type mice, as TLR2 ligands, unlike TLR4 and TLR9 agonists, augmented Treg proliferation [103]. As such, the spontaneous arthritis detected in IL-1 receptor antagonist knockout (IL1rn-/-) was more severe when these mice were backcrossed into a TLR2-/- background, and the clinical manifestations were markedly reduced when IL1rn-/- were crossed with TLR4-/- mice [104]. Notably activation of human PBMCs activated with TLR7s agonist potentiates TH-1 and TH-17 cell differentiation [105]. 
TLR4 can affect $\mathrm{T}$ cell adherence and migration since human $\mathrm{T}$ cells adhere to fibronectin via TLR4 binding, and a TLR4 agonist inhibits CXCL12 mediated T cell chemotaxis [105]. In addition to APC-provoked T cell activation, some TLRs such as TLR2, 3, 5, 7 and 9 are expressed on T cells and can directly impact $\mathrm{T}$ cell function. T cells activated with a TLR3 agonist, secrete IL-17 and IL-21, and these TLR3-driven IL21-producing cells express CXCR3, which can further contribute to T cell trafficking into the joint [106].

Most recently it was shown that ligation of TLR5 in RA PBMCs can promote TH-17 cell polarization via myeloid cell production of IL-6 and IL-1 $\beta$ [13]. IL-17 produced by the TLR5 activated PBMCs was capable of inducing endothelial cell migration. IL-17-driven angiogenesis could further potentiate TLR5 mediated inflammation and osteoclastic bone erosion [13] (Fig. 3).

Thus ligation of TLRs shifts the balance towards TH-17 cell polarization via mechanisms that in part depend on proinflammatory cytokines secreted from M1 macrophages and RA ST fibroblasts (Fig. 3).

2.5 Angiogenesis and endothelial cell function: Angiogenesis is an early and critical event in RA that promotes leukocyte infiltration and pannus formation [107-109]. Angiogenesis encompasses complex events that impact endothelial cell function, such as activation, proliferation, sprouting and finally blood vessel stabilization. Stimuli known 
to activate endothelial cells and initiate angiogenesis include hypoxia, inflammatory mediators and mechanical stress [63].

Activation of TLRs in macrophages and RA ST fibroblasts indirectly promotes angiogenesis [63]. An adenosine (A)2AR agonist synergizes with TLR2, 4, 7 and 9 ligands to increase production of vascular endothelial growth factor (VEGF) from macrophages [110]. In contrast, a TLR3 agonist inhibits VEGF production from macrophages [110]. Interesting, the natural ligand for TLR2 and TLR4, HMGB1, promotes secretion of proangiogenic factors from macrophages and RA ST fibroblasts to induce tube formation in a TLR4 dependent manner [111, 112]. Moreover, RA ST fibroblasts or explants stimulated with TLR2 agonists release elevated levels of VEGF, IL-8 and Ang-2 that can indirectly contribute to neovascularization [113, 114]. When naïve cells differentiate into M1 macrophages upon TLR4 activation, the released inflammatory factors such as TNF, IL-6, IL-1 and IL-8 can directly trigger angiogenesis (TNF and IL-8) or stimulate RA ST fibroblasts to produce higher levels of proangiogenic factors [115].

Of note, TLR5 is one of the few TLRs that are expressed on RA ST endothelial cells [14]. Hence ligation of endothelial cell TLR5 by flagellin or TLR5 natural ligands expressed in RA SF elicits endothelial migration and tube formation. TLR5 can also potentiate its angiogenic effect by promoting differentiation of TH-17 cells in RA PBMCs [13] (Fig. 3). 
These results from our group and others show that, with the exception of TLR5 that is uniquely expressed on endothelial cells and can directly affect their function, other TLRs affect RA angiogenesis by augmenting the production of proangiogenic factors from macrophages and RA ST fibroblasts.

\section{Impact of TLRs in preclinical models of RA}

A number of approaches have been utilized in acute and chronic RA preclinical models to evaluate the potential role of TLRs in RA pathology.

3.1 Role of TLR2 and TLR4 activation in preclinical RA models: Streptococcal cell wall (SCW) induced arthritis was markedly reduced in TLR2-/- mice, in part due to decreased CCL3, CCL5 and CXCL1 levels that are responsible for infiltration of inflammatory cells into the arthritic joint [116]. Interestingly, TLR2 dependency was shifted to TLR4 dependency, when SCW was repeatedly injected in TLR2-/- mice over a longer time frame [117]. In the chronic model of SCW, TLR4 deficiency resulted in impaired osteoclast formation as well as reduction in TH-17 inducing cytokines such as IL-1, IL-6 and IL-23 [117]. Hence arthritic TLR4-/- mice produced lower levels of IL-17 with no change in IFN- $\gamma$ compared to wild type mice [117]. Consistent with these observations, TLR4 antagonism ameliorated clinical and histological manifestations of collagen induced arthritis (CIA) through downregulation of joint IL-1 levels [118]. Additionally a TLR4 antagonist prevented the spontaneous arthritis in IL-1Ra-/- mice [118]. Interestingly, joint swelling was detected in IL-1 $\beta-/-$ mice when LPS was co- 
administered in the serum transfer $\mathrm{K} / \mathrm{BxN}$ arthritis model, suggesting that joint inflammation provoked via TLR4 can bypass IL-1 [119].

3.2 Impact of TLR5 ligation in RA murine models: Recent studies in CIA demonstrate that local administration of a TLR5 agonist exacerbates joint inflammation and bone erosion. This TLR5 driven inflammation is due to M1 macrophage differentiation which leads to release of IL-6 and IL-1 that can further stimulate TH-17 cell development [13, 14]. Elevated levels of IL-17 provoked by TLR5 ligation in CIA joints is involved in arthritic neovascularization [13]. Conversely, anti-TLR5 antibody treatment reduces M1 macrophage and TH-17 cell polarization [12]. Notably, TLR5 mediated osteoclastic bone erosion is in part due to induction of TNF [12]. As blockade of both TLR5 and TNF has a greater ability to abrogate RA SF mediated osteoclastogenesis than blockade of each

pathway alone [12]. Local injection of flagellin, establishes that TLR5 promotes joint inflammation and arthritic bone loss by linking the myeloid (TNF) and T (IL-17) arms of the disease [12].

\subsection{Significance of TLR3 and TLR9 function in experimental arthritis models:}

Ectopic dsRNA ligation to TLR3 promotes joint inflammation through IL-1 activation, since dsRNA induced arthritis is diminished in the IL-1R-/- mouse [120]. Consistent with this observation, $\mathrm{K} / \mathrm{BxN}$ serum transfer arthritis was markedly reduced in TLR3-/- mice through a mechanism that was partially due to interferon regulatory factor (IRF)5 signaling [121]. 
In contrast, systemic administration of a TLR3 agonist in collagen antibody induced arthritis (CAIA) alleviated arthritis by increasing type I interferons that inhibited synovial cell proliferation and inflammatory responses [122]. Likewise, co-administration of $\mathrm{CpG}$ ODNs (TLR9 agonist) together with $\mathrm{K} / \mathrm{BxN}$ serum resolved joint inflammation by potentiating IL-12 and IFN- $\gamma$ production and inhibiting synovial neutrophil infiltration [123].

3.4 Implication of TLR7 signaling in RA preclinical models: In rat CIA, pre-onset treatment with short hairpin TLR7-binding RNA ameliorated arthritis due to reduction in joint micro-vessel density and VEGF release from fibroblasts [124]. Others documented that CIA was alleviated in TLR7-/- mice, due to the suppression of the IL-17 response and elevation of joint Tregs [125]. Similarly, in the $\mathrm{K} / \mathrm{BxN}$ serum transfer arthritis model, joint inflammation was attenuated in TLR7-/- compared to wild type mice in part due to reduced serum levels of IL-1 $\beta$, CXCL1, CXCL10 and CCL3 [121].

Our group was the first to report that miR-Let7b, predominately packaged in RA SF exosomes, is an endogenous ligand for TLR7 [15]. We documented that ligation of TLR7 by local injection of miR-Let7b triggers joint inflammation and increased lining thickness in wild type mice compared to the control group. On the contrary, joint swelling was blunted in TLR7 deficient mice that received ectopic injection of adenovirus (Ad)-Let7b or Ad-Ctl, signifying that ligation of miR-Let7b to TLR7 is responsible for arthritis induction. We found that local injection of miR-Let7b provokes arthritic joint inflammation by recruiting myeloid cells from the circulation into joint and further 
transforming them into M1 macrophages that secrete high levels of TNF, IL-1, IL-6, CCL2, CCL5 and express the M1 marker iNOS [15].

Altogether, the data suggest that activation of TLR4, TLR5 and TLR7 has critical implications for joint inflammation and bone destruction observed in RA preclinical models. However, ligation of TLR2, TLR3 and TLR9 may have dual effects on disease manifestations depending on the experimental arthritis model employed.

\section{Therapeutic approaches targeting TLRs:}

Use of biologics has improved RA patient care, however there is a percent of patients that do not tolerate or respond to these therapies. Given that TLRs play an instrumental role in RA pathology a number of strategies have been developed to target TLR driven inflammatory response.

These strategies include: 1) using soluble decoy receptors or neutralizing antibodies that block the ligand-receptor interaction, 2) impairing receptor dimerization, 3) inhibiting the release of endogenous ligands or the TLR expression levels and 4) suppressing TLR associated downstream pathways.

4.1 TLR2/4 blockade: There are antagonistic antibodies generated against TLR2 and TLR4 which are still at the preclinical phase (reviewed in $[11,126,127])$. OPN305 (Opsona Therapeutics), a blocking antibody that abrogates TLR2/TLR1 and TLR2/TLR6 activation and release of proinflammatory cytokines, is currently in the preclinical phase 
[11]. OPN305 blockade of TLR2 activity on human monocytes was well tolerated in healthy individuals [128]. A different antibody, OPN301, constructed by Opsona therapeutics, was as effective as anti-TNF antibody in inhibiting the spontaneous production of proinflammatory factors from RA explants [129]. The TLR4 monoclonal antibody, NI0101, generated by NovImmune is in a preclinical phase [11]. NI0101 binds to an epitope on TLR4 and compromises its dimerization and activation. The synthetic Lipid A antagonist, eritoran (E5564; Eisai Pharmaceuticals), prevents LPS from binding to the MD2-TLR4 receptor complex [126]. Additionally, eritoran downregulates LPS induced cytokine production in human monocytes, the effects of LPS inhalation and sepsis in experimental models [130]. Eritoran is in phase III, however the compound needs to be administrated repeatedly to elicit a therapeutic response [126].

4.2 Targeting TLR3/7/9 activation: The anti-malarial drug, choloroquine, inhibits lysoendosomal acidification of TLR3, 7, 8 and 9. Consequently, choloroquine interferes with chemotaxis, phagocytosis and antigen presentation mediated by endosomal TLRs [131]. Additionally the antidepressant drugs, fluoxetine and citalopram, inhibit endosomal TLRs and have shown to alleviate CIA and reduce RA synovial membrane mediated cytokine production [132]. Currently, Idera is developing a DNA-based TLR7/9 antagonist, IMO-3100, for RA, SLE and psoriasis treatment. The phase I studies demonstrated that this compound was well tolerated and decreased TNF and IL-1 production in human donors [11]. Dynavaz is also in the process of developing a DNA based compound against TLR7/TLR9 (DV-1179) which is in the preclinical stage [11]. 


\subsection{Targeting endogenous ligands or reducing the synovial TLR expression levels}

Neutralizing antibody or a truncated version of HMGB1, an endogenous ligand for TLR2 and TLR4, ameliorated CIA [133]. An inhibitor for HSP90 was also capable of resolving joint inflammation in rat CIA [134]. Despite findings in murine models, given that there are numerous TLR2 and TLR4 natural ligands detected in RA joint, blocking a single ligand may not efficiently suppress TLR2 and TLR4 function. Certain mi-RNAs can post-transcriptionally impact TLR expression, associated transcription factors and TLR induced cytokines. As such, it is shown that miR-21, miR-147 and miR-155 modulate cell surface TLR2/4 frequency and their downstream signaling mediators including NF$\mathrm{kB}$ and IRF3 [135]. In monocytes, TLR4 induced tolerance is due to release of miR-146, as levels of miR-146 inversely correlate with LPS induced TNF production [136].

\subsection{Targeting TLR downstream pathways}

A selective p38 MAPK inhibitor, papamimod, resolved clinical manifestations in an RA

preclinical model, yet this p38 inhibitor was less efficacious than MTX $[137,138]$. A different p38 MAPK inhibitor synthetized by GlaxoSmithKline is currently in phase I clinical trial [11]. MLN-0415, an IKK $\beta$ inhibitor developed by Millennium to target the NF- $\kappa$ B pathway, was discontinued at phase I, because of its adverse effects. RDP-58, a decapeptide that targets IRAK complex formation, is in phase II clinical trials for Crohn's disease and ulcerative colitis [139, 140]. 


\section{CONCLUSIONS AND FUTURE DIRECTIONS}

It is postulated that harmful stimuli triggered by injury, infection, stress, hypoxia or cell death, ignite tissue damage and release of endogenous TLR ligands (Fig. 1). Binding of these TLR ligands to the responsive cells can lead to chronic inflammation that results in cartilage and bone destruction. In the last decade, evidence from RA specimen and preclinical models have allowed us to unravel novel endogenous ligands for TLRs and to gain insight into the mechanism by which binding of these natural ligands to their corresponding receptors promotes disease. There is no cure for RA and up to $40 \%$ of the heterogeneous RA patient population does not respond to anti-TNF therapies [141]. Circulating TH-17 cells or IL-17 levels are highly elevated subsequent to TNF blockade in the non-responder population $[142,143]$. Ligation of TLR4, 5 and 7 has been shown to promote TH-17 differentiation via IL-6 and IL-1 production from M1 macrophages, suggesting that these receptors may play a critical role in linking the myeloid and $\mathrm{T}$ cell arms of the disease. Earlier studies have implied that targeting TLR downstream pathways may not be desirable because of their functional redundancy. Likewise, TLR natural ligands are promiscuous and each receptor may bind to various ligands. Hence uncovering novel strategies to halt TLR activation as well as identifying RA patients who will respond to these therapies are among the challenges that, if met, can ultimately provide more cost effective personalized care. 


\section{FIGURE LEGENDS}

Figure 1. Schematic figure illustrating the mechanism by which harmful stimuli can potentially activate release of TLR endogenous ligand that triggers TLR mediated inflammatory joint damage. Harmful stimuli such as injury, infection, stress and hypoxia promote tissue and cell death. As a result, endogenous ligands are released into RA synovial fluid where they can bind directly to cells that express TLRs such as RA macrophages, synovial tissue fibroblasts and pre-osteoclasts or affect cell (endothelial cells and TH-17 cell) function indirectly through production of inflammatory factors. The combined direct and indirect effects of TLR ligation facilitate inflammation, angiogenesis, TH-17 cell polarization and osteoclastic bone erosion which ultimately sustains the vicious cycle of inflammatory bone destruction.

Figure 2. Cell surface and endosomally expressed TLRs point to potential therapeutic approaches targeting TLR mode of action. TLRs are classified into two groups based on their distribution and ligand selection. TLRs 1, 2, 4, 5 and 6 are expressed on the cell surface and recognize microbial components, whereas, endosomal TLRs 3, 7, 8 and 9 primarily detect nucleic acids. There are a number of strategies utilized to abrogate TLR driven inflammatory responses. These strategies include: 1) use of soluble decoy receptors or neutralizing antibodies that abolish the ligand and receptor binding, 2) suppressing the production of endogenous ligands or the TLR expression levels, 3) inhibiting the TLR linked downstream pathways and 4) inhibiting TLR expression in part through mi-RNAs. 
Figure 3. Schematic figure illustrating the mechanism by which TLR ligands potentiate RA pathology. Ligation of TLR4, 5 and 7 can transform RA myeloid cells into M1 macrophages and as a result the inflammatory factors released from M1 and RA ST fibroblasts participate in TH-17 cell polarization. Ligation of TLR5 via flagellin or TLR5 natural ligands expressed in RA SF transforms RA myeloid cells into mature osteoclasts. RA osteoclastogenesis is exacerbated through joint neovascularization mediated directly through TLR5 ligation or indirectly via TH-17 driven angiogenesis. 


\begin{tabular}{|c|c|c|c|c|c|c|}
\hline$T L R$ & Localization & Exogenous ligands & $\begin{array}{c}\text { Endogenous } \\
\text { ligands }\end{array}$ & $\begin{array}{l}\text { Signaling } \\
\text { adaptors }\end{array}$ & $\begin{array}{c}\text { Transcription } \\
\text { Factors }\end{array}$ & $\begin{array}{c}\text { Cell } \\
\text { Expression }\end{array}$ \\
\hline TLRI & $\begin{array}{l}\text { Plasma } \\
\text { membrane }\end{array}$ & $\begin{array}{c}\text { Synthetic } \\
\text { triacetylated } \\
\text { lipopeptide } \\
\text { (Pam3CSK4), } \\
\text { tri-acetylated } \\
\text { lipopeptides coupled } \\
\text { to peptidoglycan }\end{array}$ & & MyD88 & $\begin{array}{c}\text { NF-кB, AP1, } \\
\text { IRF1/5/7 }\end{array}$ & $\begin{array}{l}\text { Monocytes, } \\
\text { M } \phi \text { s, B and } \\
\text { T cells, NK } \\
\text { cells, DCs, } \\
\text { PMN, RA } \\
\text { fib., RA ST }\end{array}$ \\
\hline$T L R 2$ & $\begin{array}{l}\text { Plasma } \\
\text { membrane }\end{array}$ & $\begin{array}{c}\text { Pam3CSK4, } \\
\text { Lipoarabinomannan } \\
\text { (LAM), LPS, } \\
\text { lipoteichoic acid } \\
\text { (LTA), PGN, and } \\
\text { other glycolipids, } \\
\text { glycoproteins, and } \\
\text { lipoproteins } \\
\text { Zymosan, protozoa } \\
\text { and some viruses }\end{array}$ & $\begin{array}{l}\text { HSP60,70, } \\
\text { biglycan, } \\
\text { GP96, } \\
\text { HMGB1, } \\
\text { Surfactant } \\
\text { protein A/D, } \\
\text { HA } \\
\text { fragment }\end{array}$ & MyD88 & $\begin{array}{c}\text { NF-кB, AP1, } \\
\text { IRF1/5/7 }\end{array}$ & $\begin{array}{c}\text { RA } \\
\text { monocyes, } \\
\text { RA SF } \\
\text { M } \phi s, \text { RA } \\
\text { fib., RA } \\
\text { ST, and } \\
\text { PBLs }\end{array}$ \\
\hline TLR4 & $\begin{array}{l}\text { Plasma } \\
\text { membrane }\end{array}$ & $\begin{array}{c}\text { LPS, } \\
\text { fungal mannan and } \\
\text { glucuronoxylmannan, } \\
\text { protozoa, and some } \\
\text { viruses }\end{array}$ & $\begin{array}{c}\text { HSP60,70, } \\
\text { biglycan, } \\
\text { GP96, } \\
\text { HMGB1, } \\
\text { Surfactant } \\
\text { protein A/D, } \\
\text { HA } \\
\text { fragment } \\
\text { Oxidized } \\
\text { LDL, } \\
\text { saturated } \\
\text { fatty acids, } \\
\text { serum } \\
\text { amyloid A, } \\
\text { fibronectin } \\
\text { EDA, } \\
\text { SS100A8/A } \\
9\end{array}$ & $\begin{array}{c}\text { TRIF, } \\
\text { MyD88 }\end{array}$ & 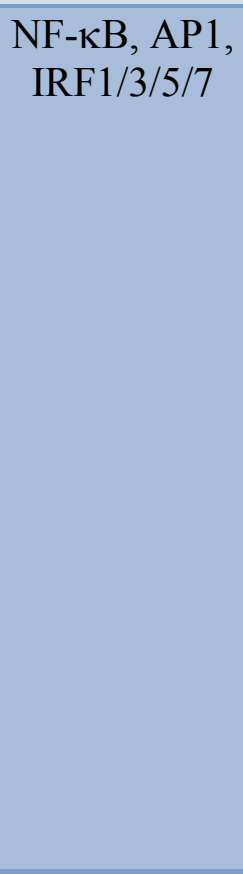 & $\begin{array}{l}\text { RA mono, } \\
\text { RA SF } \\
\text { M } \phi s, \text { RA } \\
\text { fib., RA } \\
\text { ST, and } \\
\text { PBLs }\end{array}$ \\
\hline TLR5 & $\begin{array}{l}\text { Plasma } \\
\text { membrane }\end{array}$ & Flagellin & $\begin{array}{l}\text { Ligands } \\
\text { present in } \\
\text { RA synovial } \\
\text { fluid }\end{array}$ & MyD88 & $\begin{array}{c}\text { NF-кB, AP1, } \\
\text { IRF1/5/7 }\end{array}$ & $\begin{array}{c}\text { PBLs } \\
\text { mostly } \\
\text { Monocytes, } \\
\text { RA SF } \\
\text { M } \phi \text { s, RA } \\
\text { fib., Endo, } \\
\text { RA ST }\end{array}$ \\
\hline TLR6 & $\begin{array}{l}\text { Plasma } \\
\text { membrane }\end{array}$ & $\begin{array}{l}\text { Pam3CSK4, diacyl } \\
\text { lipopeptides, LTA, }\end{array}$ & $\begin{array}{l}\text { Versican, } \\
\text { HA }\end{array}$ & MyD88 & $\begin{array}{l}\text { NF-кB, AP1, } \\
\text { IRF } 1 / 5 / 7\end{array}$ & $\begin{array}{c}\text { PBLs } \\
\text { highest on }\end{array}$ \\
\hline
\end{tabular}




\begin{tabular}{|c|c|c|c|c|c|c|}
\hline & & $\begin{array}{l}\text { protozoa, and } \\
\text { Zymosan }\end{array}$ & $\begin{array}{l}\text { fragments, } \\
\text { PAUF }\end{array}$ & & & $\begin{array}{c}\text { Monocytes } \\
\text { and B cells, } \\
\text { M } \phi \text { s, RA } \\
\text { fib. }\end{array}$ \\
\hline TLR3 & Endosome & $\begin{array}{c}\text { Synthetic Poly I:C } \\
\text { and Poly A:U, and } \\
\text { Viral dsRNA }\end{array}$ & $\begin{array}{l}\text { RNA } \\
\text { released } \\
\text { from } \\
\text { necrotic } \\
\text { cells }\end{array}$ & TRIF & NF-кB, IRF3 & $\begin{array}{l}\text { RA fib., } \\
\text { DCs, T } \\
\text { cells, } \\
\text { grnaulocyte } \\
\text { s, and } \\
\text { monocytes. }\end{array}$ \\
\hline TLR7 & Endosome & $\begin{array}{l}\text { Viral ssRNA, GU } \\
\text { rich oligos, and } \\
\text { synthetic } \\
\text { imidazoquinoline } \\
\text { derivatives }\end{array}$ & $\begin{array}{l}\text { RA synovial } \\
\text { fluid } \\
\text { ssRNA, } \\
\text { miR-let7b, } \\
\text { miR-29a }\end{array}$ & MyD88 & $\begin{array}{l}\text { NF-кB, AP1, } \\
\text { IRF1/5/7 }\end{array}$ & $\begin{array}{l}\text { Monocytes, } \\
\text { RA SF } \\
\text { M } \phi \text { s, RA } \\
\text { fib, B cells, } \\
\text { RA ST }\end{array}$ \\
\hline TLRB & Endosome & $\begin{array}{c}\text { Viral ssRNA, and } \\
\text { synthetic } \\
\text { thiazoloquinolone } \\
\text { derivative (CL075) }\end{array}$ & $\begin{array}{l}\text { Not } \\
\text { identified } \\
\text { but probably } \\
\text { RA synovial } \\
\text { fluid ssRNA }\end{array}$ & MyD88 & $\begin{array}{l}\text { NF-кB, AP1, } \\
\text { IRF1/5/7 }\end{array}$ & $\begin{array}{l}\text { Monocytes, } \\
\text { RA SF } \\
\text { M } \phi \text { s, RA } \\
\text { ST }\end{array}$ \\
\hline TLR9 & Endosome & $\begin{array}{c}\text { Non methylated CpG } \\
\text { bacterial DNA } \\
\text { (ODN2006) }\end{array}$ & $\begin{array}{c}\text { DNA } \\
\text { containing } \\
\text { CpG } \\
\text { ribosomal } \\
\text { repeats, } \\
\text { DNA- } \\
\text { immune } \\
\text { complexes } \\
\text { (IC), IgG- } \\
\text { chromatin } \\
\text { complexes }\end{array}$ & MyD88 & $\begin{array}{l}\text { NF-кB, AP1, } \\
\text { IRF1/5/7 }\end{array}$ & $\begin{array}{l}\text { PBLs } \\
\text { highest in } \\
\text { B cells and } \\
\text { DCs }\end{array}$ \\
\hline TLR10 & Endosome & Same as TLR2 & $\begin{array}{l}\text { Not } \\
\text { identified }\end{array}$ & MyD88 & $\begin{array}{l}\text { NF-кB, AP1, } \\
\text { IRF } 1 / 5 / 7\end{array}$ & $\begin{array}{c}\text { Expression, } \\
\text { only in } \\
\text { humans } \\
\text { and not } \\
\text { mice, on } \\
\text { leukocytes } \\
\text { but highest } \\
\text { on B cells }\end{array}$ \\
\hline
\end{tabular}

Table 1. The characteristics of TLRs are summarized in this table. 


\section{TAKE-HOME MESSAGES}

- TLRs ligate to their natural ligands expressed in the RA joint to provoke joint inflammation and osteoclastic bone destruction

- $\quad$ RA ST fibroblasts, M1 macrophages, TH-17 cells, mature osteoclasts and endothelial cells play critical roles in TLR-mediated RA pathology

- $\quad$ Ligation of distinct TLRs can transform RA myeloid cells into M1 macrophages, and as a result the inflammatory factors released from M1 and RA ST fibroblasts promote TH-17 cell polarization

- $\quad$ Specific TLR function can interconnect myeloid and the T cell arms of the disease - Novel approaches are being tested to target TLR function

\section{DISCLOSURE}

No conflict of interest disclosed.

\section{ACKNOWLEDGEMENTS}

This work was supported in part by awards from Department of Veteran's Affairs MERIT Award 1I01BX002286, the National Institutes of Health AR056099 and AR065778, funding provided by Department of Defense PR093477 and Arthritis Foundation Innovative Research Grant. We would like to apologize to colleagues whose work was not cited due to space limitations. 


\section{ABBREVIATIONS}

RA; rheumatoid arthritis, TLR; Toll like receptor, TH-17; T helper cells that produced IL-17A, DCs; dendritic cells, PMNs; poly mononuclear cells, PAMPs; pathogenassociated molecular patterns , DAMPs; damage-associated molecular patterns, HMGB1; high mobility group box, HSP; heat shock protein, PB; peripheral blood, SF; synovial fluid, SNPs; single nucleotide polymorphisms, DAS28; RA disease activity, TRIF; TIRdomain-containing adapter-inducing interferon- $\beta$, IFN; interferon, ST; synovial tissue, ssRNA; single strand RNA, dsRNA; double stand RNA; NL; normal, DMARDs; diseasemodifying anti-rheumatic drugs, RANK; receptor activator for nuclear factor $\mathrm{\kappa B}$, RANKL, receptor activator for nuclear factor $\mathrm{\kappa B}$ ligand; MRP; myeloid related protein, ROR; retinoic acid related orphan receptor, Tregs; T regulatory cells, IL1rn-/-; IL-1 receptor antagonist knockout, Ad; adenovirus, VEGF; vascular endothelial growth factor, CAIA; collagen antibody induced arthritis, CIA; collaged induced arthritis, SCW; streptococcal cell wall arthritis, IRF5; interferon regulatory factor 5, MMPs; matrix metalloproteinases, ICAM; intercellular adhesion molecule. 


\section{REFERENCES}

[1] G.S. Firestein. Evolving concepts of rheumatoid arthritis. Nature 2003; 423: 35661.

[2] I.B. McInnes and G. Schett. Cytokines in the pathogenesis of rheumatoid arthritis. Nat. Rev. Immunol. 2007; 7: 429-42.

[3] F.M. Brennan and I.B. McInnes. Evidence that cytokines play a role in rheumatoid arthritis. J. Clin. Invest. 2008; 118: 3537-45.

[4] I.B. McInnes, C.D. Buckley and J.D. Isaacs. Cytokines in rheumatoid arthritis shaping the immunological landscape. Nat. Rev. Rheumatol. 2016; 12: 63-8.

[5] Z. Szekanecz and A.E. Koch. Successes and failures of chemokine-pathway targeting in rheumatoid arthritis. Nat. Rev. Rheumatol. 2016; 12: 5-13.

[6] L. Klareskog, L. Padyukov, J. Ronnelid and L. Alfredsson. Genes, environment and immunity in the development of rheumatoid arthritis. Curr. Opin. Immunol. 2006; 18: 650-5.

[7] Y. Kochi, A. Suzuki, R. Yamada and K. Yamamoto. Ethnogenetic heterogeneity of rheumatoid arthritis-implications for pathogenesis. Nat. Rev. Rheumatol. 2010; 6: $290-5$.

[8] L.A. O'Neill. Primer: Toll-like receptor signaling pathways--what do rheumatologists need to know? Nat. Clin. Pract. Rheumatol. 2008; 4: 319-27.

[9] M.J. Jimenez-Dalmaroni, M.E. Gerswhin and I.E. Adamopoulos. The critical role of toll-like receptors - From microbial recognition to autoimmunity: A comprehensive review. Autoimmunity reviews 2016; 15: 1-8. 
[10] Q.Q. Huang and R.M. Pope. The role of glycoprotein 96 in the persistent inflammation of rheumatoid arthritis. Arch. Biochem. Biophys. 2013; 530: 1-6.

[11] F.G. Goh and K.S. Midwood. Intrinsic danger: activation of Toll-like receptors in rheumatoid arthritis. Rheumatology (Oxford) 2012; 51: 7-23.

[12] S.J. Kim, Z. Chen, N.D. Chamberlain, A.B. Essani, M.V. Volin, M.A. Amin, S. Volkov, E.M. Gravallese, S. Arami, W. Swedler, N.E. Lane, A. Mehta, N. Sweiss and S. Shahrara. Ligation of TLR5 Promotes Myeloid Cell Infiltration and Differentiation into Mature Osteoclasts in Rheumatoid Arthritis and Experimental Arthritis. J. Immunol. 2014; 193: 3902-13.

[13] S.J. Kim, Z. Chen, N.D. Chamberlain, M.V. Volin, W. Swedler, S. Volkov, N. Sweiss and S. Shahrara. Angiogenesis in Rheumatoid Arthritis Is Fostered Directly by Toll-like Receptor 5 Ligation and Indirectly Through Interleukin-17 Induction. Arthritis Rheum. 2013; 65: 2024-36.

[14] N.D. Chamberlain, O.M. Vila, M.V. Volin, S. Volkov, R.M. Pope, W. Swedler, A.M. Mandelin, 2nd and S. Shahrara. TLR5, a novel and unidentified inflammatory mediator in rheumatoid arthritis that correlates with disease activity score and joint TNF-alpha levels. J. Immunol. 2012; 189: 475-83.

[15] S.J. Kim, Z. Chen, A.B. Essani, H.A. Elshabrawy, M.V. Volin, S. Volkov, W. Swedler, S. Arami, N. Sweiss and S. Shahrara. Identification of a novel TLR7 endogenous ligand in RA synovial fluid that can provoke arthritic joint inflammation. Arthritis Rheumatol 2015.

[16] N.D. Chamberlain, S.J. Kim, O.M. Vila, M.V. Volin, S. Volkov, R.M. Pope, S. Arami, A.M. Mandelin, 2nd and S. Shahrara. Ligation of TLR7 by rheumatoid 
arthritis synovial fluid single strand RNA induces transcription of TNFalpha in monocytes. Annals of the Rheumatic Diseases. 2013; 72: 418-26.

[17] T. Kawai and S. Akira. The role of pattern-recognition receptors in innate immunity: update on Toll-like receptors. Nat. Immunol. 2010; 11: 373-84.

[18] M.S. Jin, S.E. Kim, J.Y. Heo, M.E. Lee, H.M. Kim, S.G. Paik, H. Lee and J.O. Lee. Crystal structure of the TLR1-TLR2 heterodimer induced by binding of a triacylated lipopeptide. Cell 2007; 130: 1071-82.

[19] C. Ospelt and S. Gay. TLRs and chronic inflammation. Int. J. Biochem. Cell Biol. 2010; 42: 495-505.

[20] J.Y. Kang, X. Nan, M.S. Jin, S.J. Youn, Y.H. Ryu, S. Mah, S.H. Han, H. Lee, S.G. Paik and J.O. Lee. Recognition of lipopeptide patterns by Toll-like receptor 2-Toll-like receptor 6 heterodimer. Immunity 2009; 31: 873-84.

[21] S. Saitoh, S. Akashi, T. Yamada, N. Tanimura, M. Kobayashi, K. Konno, F. Matsumoto, K. Fukase, S. Kusumoto, Y. Nagai, Y. Kusumoto, A. Kosugi and K. Miyake. Lipid A antagonist, lipid IVa, is distinct from lipid A in interaction with Toll-like receptor 4 (TLR4)-MD-2 and ligand-induced TLR4 oligomerization. Int. Immunol. 2004; 16: 961-9.

[22] B.U. Mueller, F. Jacobsen, K.M. Butler, R.N. Husson, L.L. Lewis and P.A. Pizzo. Combination treatment with azidothymidine and granulocyte colony-stimulating factor in children with human immunodeficiency virus infection. J. Pediatr. 1992; 121: 797-802.

[23] A. Ozinsky, D.M. Underhill, J.D. Fontenot, A.M. Hajjar, K.D. Smith, C.B. Wilson, L. Schroeder and A. Aderem. The repertoire for pattern recognition of 
pathogens by the innate immune system is defined by cooperation between tolllike receptors. Proc. Natl. Acad. Sci. U. S. A. 2000; 97: 13766-71.

[24] A.M. Hajjar, D.S. O'Mahony, A. Ozinsky, D.M. Underhill, A. Aderem, S.J. Klebanoff and C.B. Wilson. Cutting edge: functional interactions between tolllike receptor (TLR) 2 and TLR1 or TLR6 in response to phenol-soluble modulin. J. Immunol. 2001; 166: 15-9.

[25] C.A. Janeway, Jr. and R. Medzhitov. Innate immune recognition. Annu. Rev. Immunol. 2002; 20: 197-216.

[26] G.M. Barton and R. Medzhitov. Toll-like receptors and their ligands. Curr. Top. Microbiol. Immunol. 2002; 270: 81-92.

[27] R. Medzhitov. Toll-like receptors and innate immunity. Nat. Rev. Immunol. 2001; 1: $135-45$.

[28] T. Compton, E.A. Kurt-Jones, K.W. Boehme, J. Belko, E. Latz, D.T. Golenbock and R.W. Finberg. Human cytomegalovirus activates inflammatory cytokine responses via CD14 and Toll-like receptor 2. J. Virol. 2003; 77: 4588-96.

[29] U. Duesberg, A. von dem Bussche, C. Kirschning, K. Miyake, T. Sauerbruch and U. Spengler. Cell activation by synthetic lipopeptides of the hepatitis $\mathrm{C}$ virus (HCV)--core protein is mediated by toll like receptors (TLRs) 2 and 4. Immunol. Lett. 2002; 84: 89-95.

[30] S. Uematsu and S. Akira. Toll-Like receptors (TLRs) and their ligands. Handb. Exp. Pharmacol. 2008; 1-20.

[31] A. Kol, A.H. Lichtman, R.W. Finberg, P. Libby and E.A. Kurt-Jones. Cutting edge: heat shock protein (HSP) 60 activates the innate immune response: CD14 is 
an essential receptor for HSP60 activation of mononuclear cells. J. Immunol. 2000; 164: 13-7.

[32] H.S. Hreggvidsdottir, T. Ostberg, H. Wahamaa, H. Schierbeck, A.C. Aveberger, L. Klevenvall, K. Palmblad, L. Ottosson, U. Andersson and H.E. Harris. The alarmin HMGB1 acts in synergy with endogenous and exogenous danger signals to promote inflammation. J. Leukoc. Biol. 2009; 86: 655-62.

[33] T. Warger, N. Hilf, G. Rechtsteiner, P. Haselmayer, D.M. Carrick, H. Jonuleit, P. von Landenberg, H.G. Rammensee, C.V. Nicchitta, M.P. Radsak and H. Schild. Interaction of TLR2 and TLR4 ligands with the N-terminal domain of Gp96 amplifies innate and adaptive immune responses. J. Biol. Chem. 2006; 281: 22545-53.

[34] C. Ospelt, F. Brentano, Y. Rengel, J. Stanczyk, C. Kolling, P.P. Tak, R.E. Gay, S. Gay and D. Kyburz. Overexpression of toll-like receptors 3 and 4 in synovial tissue from patients with early rheumatoid arthritis: toll-like receptor expression in early and longstanding arthritis. Arthritis Rheum. 2008; 58: 3684-92.

[35] R. Seibl, T. Birchler, S. Loeliger, J.P. Hossle, R.E. Gay, T. Saurenmann, B.A. Michel, R.A. Seger, S. Gay and R.P. Lauener. Expression and regulation of Tolllike receptor 2 in rheumatoid arthritis synovium. Am. J. Pathol. 2003; 162: 12217.

[36] Q. Huang, Y. Ma, A. Adebayo and R.M. Pope. Increased macrophage activation mediated through toll-like receptors in rheumatoid arthritis. Arthritis Rheum. 2007; 56: 2192-201. 
[37] M. Iwahashi, M. Yamamura, T. Aita, A. Okamoto, A. Ueno, N. Ogawa, S. Akashi, K. Miyake, P.J. Godowski and H. Makino. Expression of Toll-like receptor 2 on $\mathrm{CD} 16+$ blood monocytes and synovial tissue macrophages in rheumatoid arthritis. Arthritis Rheum. 2004; 50: 1457-67.

[38] T.R. Radstake, M.F. Roelofs, Y.M. Jenniskens, B. Oppers-Walgreen, P.L. van Riel, P. Barrera, L.A. Joosten and W.B. van den Berg. Expression of toll-like receptors 2 and 4 in rheumatoid synovial tissue and regulation by proinflammatory cytokines interleukin-12 and interleukin-18 via interferongamma. Arthritis Rheum. 2004; 50: 3856-65.

[39] O. Jaen, E. Petit-Teixeira, H. Kirsten, P. Ahnert, L. Semerano, C. Pierlot, F. Cornelis, M.C. Boissier and G. Falgarone. No evidence of major effects in several Toll-like receptor gene polymorphisms in rheumatoid arthritis. Arthritis Res. Ther. 2009; 11: R5.

[40] M.L. Davis, T.D. LeVan, F. Yu, H. Sayles, J. Sokolove, W. Robinson, K. Michaud, G.M. Thiele and T.R. Mikuls. Associations of toll-like receptor (TLR)4 single nucleotide polymorphisms and rheumatoid arthritis disease progression: an observational cohort study. Int. Immunopharmacol. 2015; 24: 346-52.

[41] V. Hornung, S. Rothenfusser, S. Britsch, A. Krug, B. Jahrsdorfer, T. Giese, S. Endres and G. Hartmann. Quantitative expression of toll-like receptor 1-10 mRNA in cellular subsets of human peripheral blood mononuclear cells and sensitivity to CpG oligodeoxynucleotides. J. Immunol. 2002; 168: 4531-7.

[42] S. Akira, S. Uematsu and O. Takeuchi. Pathogen recognition and innate immunity. Cell 2006; 124: 783-801. 
[43] L. Liu, I. Botos, Y. Wang, J.N. Leonard, J. Shiloach, D.M. Segal and D.R. Davies. Structural basis of toll-like receptor 3 signaling with double-stranded RNA. Science 2008; 320: 379-81.

[44] K.A. Zarember and P.J. Godowski. Tissue expression of human Toll-like receptors and differential regulation of Toll-like receptor mRNAs in leukocytes in response to microbes, their products, and cytokines. J. Immunol. 2002; 168: 55461.

[45] M. Muzio, D. Bosisio, N. Polentarutti, G. D'Amico, A. Stoppacciaro, R. Mancinelli, C. van't Veer, G. Penton-Rol, L.P. Ruco, P. Allavena and A. Mantovani. Differential expression and regulation of toll-like receptors (TLR) in human leukocytes: selective expression of TLR3 in dendritic cells. J. Immunol. 2000; 164: 5998-6004.

[46] M. Rehli. Of mice and men: species variations of Toll-like receptor expression. Trends Immunol. 2002; 23: 375-8.

[47] F. Brentano, O. Schorr, R.E. Gay, S. Gay and D. Kyburz. RNA released from necrotic synovial fluid cells activates rheumatoid arthritis synovial fibroblasts via Toll-like receptor 3. Arthritis Rheum. 2005; 52: 2656-65.

[48] M.J. Laska, B. Hansen, A. Troldborg, T. Lorenzen, K. Stengaard-Pedersen, P. Junker, B.A. Nexo and H.M. Lindegaard. A non-synonymous single-nucleotide polymorphism in the gene encoding Toll-like Receptor 3 (TLR3) is associated with sero-negative rheumatoid arthritis (RA) in a Danish population. BMC Res. Notes 2014; 7: 716. 
[49] E.O. Etem, H. Elyas, S. Ozgocmen, A. Yildirim and A. Godekmerdan. The investigation of toll-like receptor 3,9 and 10 gene polymorphisms in Turkish rheumatoid arthritis patients. Rheumatol. Int. 2011;31: 1369-74.

[50] W. Zhu, L. Meng, C. Jiang, X. He, W. Hou, P. Xu, H. Du, R. Holmdahl and S. Lu. Arthritis is associated with T-cell-induced upregulation of Toll-like receptor 3 on synovial fibroblasts. Arthritis Res. Ther. 2011; 13: R103.

[51] M.F. Roelofs, M.H. Wenink, F. Brentano, S. Abdollahi-Roodsaz, B. OppersWalgreen, P. Barrera, P.L. van Riel, L.A. Joosten, D. Kyburz, W.B. van den Berg and T.R. Radstake. Type I interferons might form the link between Toll-like receptor (TLR) 3/7 and TLR4-mediated synovial inflammation in rheumatoid arthritis (RA). Annals of the Rheumatic Diseases. 2009; 68: 1486-93.

[52] O. Demaria, P.P. Pagni, S. Traub, A. de Gassart, N. Branzk, A.J. Murphy, D.M. Valenzuela, G.D. Yancopoulos, R.A. Flavell and L. Alexopoulou. TLR8 deficiency leads to autoimmunity in mice. J. Clin. Invest. 2010; 120: 3651-62.

[53] L.M. Imbertson, J.M. Beaurline, A.M. Couture, S.J. Gibson, R.M. Smith, R.L. Miller, M.J. Reiter, T.L. Wagner and M.A. Tomai. Cytokine induction in hairless mouse and rat skin after topical application of the immune response modifiers imiquimod and S-28463. J. Invest. Dermatol. 1998; 110: 734-9.

[54] H. Hemmi, O. Takeuchi, T. Kawai, T. Kaisho, S. Sato, H. Sanjo, M. Matsumoto, K. Hoshino, H. Wagner, K. Takeda and S. Akira. A Toll-like receptor recognizes bacterial DNA. Nature 2000; 408: 740-5.

[55] N.N. Veiko, N.O. Shubaeva, S.M. Ivanova, A.I. Speranskii, N.A. Lyapunova and D.M. Spitkovskii. Blood serum DNA in patients with rheumatoid arthritis is 
considerably enriched with fragments of ribosomal repeats containing immunostimulatory CpG-motifs. Bull. Exp. Biol. Med. 2006; 142: 313-6.

[56] A. Chaturvedi, D. Dorward and S.K. Pierce. The B cell receptor governs the subcellular location of Toll-like receptor 9 leading to hyperresponses to DNAcontaining antigens. Immunity 2008; 28: 799-809.

[57] B. He, X. Qiao and A. Cerutti. CpG DNA induces IgG class switch DNA recombination by activating human $\mathrm{B}$ cells through an innate pathway that requires TLR9 and cooperates with IL-10. J. Immunol. 2004; 173: 4479-91.

[58] F. Hu, R. Mu, J. Zhu, L. Shi, Y. Li, X. Liu, W. Shao, G. Li, M. Li, Y. Su, P.L. Cohen, X. Qiu and Z. Li. Hypoxia and hypoxia-inducible factor-1alpha provoke toll-like receptor signalling-induced inflammation in rheumatoid arthritis. Annals of the Rheumatic Diseases. 2014; 73: 928-36.

[59] S.L. Jongbloed, M.C. Lebre, A.R. Fraser, J.A. Gracie, R.D. Sturrock, P.P. Tak and I.B. McInnes. Enumeration and phenotypical analysis of distinct dendritic cell subsets in psoriatic arthritis and rheumatoid arthritis. Arthritis Res. Ther. 2006; 8: R15.

[60] S.M. Lee, K.H. Kok, M. Jaume, T.K. Cheung, T.F. Yip, J.C. Lai, Y. Guan, R.G. Webster, D.Y. Jin and J.S. Peiris. Toll-like receptor 10 is involved in induction of innate immune responses to influenza virus infection. Proc. Natl. Acad. Sci. U. S. A. $2014 ; 111: 3793-8$.

[61] M. Oosting, S.C. Cheng, J.M. Bolscher, R. Vestering-Stenger, T.S. Plantinga, I.C. Verschueren, P. Arts, A. Garritsen, H. van Eenennaam, P. Sturm, B.J. Kullberg, A. Hoischen, G.J. Adema, J.W. van der Meer, M.G. Netea and L.A. Joosten. 
Human TLR10 is an anti-inflammatory pattern-recognition receptor. Proc. Natl. Acad. Sci. U. S. A. 2014; 111: E4478-84.

[62] A. Kennedy, U. Fearon, D.J. Veale and C. Godson. Macrophages in synovial inflammation. Front. Immunol. 2011;2: 52.

[63] H.A. Elshabrawy, Z. Chen, M.V. Volin, S. Ravella, S. Virupannavar and S. Shahrara. The pathogenic role of angiogenesis in rheumatoid arthritis. Angiogenesis 2015; 18: 433-48.

[64] Y. Tamaki, Y. Takakubo, T. Hirayama, Y.T. Konttinen, S.B. Goodman, M. Yamakawa and M. Takagi. Expression of Toll-like receptors and their signaling pathways in rheumatoid synovitis. J. Rheumatol. 2011; 38: 810-20.

[65] S. Das, K. Pandey, A. Kumar, A.H. Sardar, B. Purkait, M. Kumar, S. Kumar, V.N. Ravidas, S. Roy, D. Singh and P. Das. TGF-beta1 re-programs TLR4 signaling in L. donovani infection: enhancement of SHP-1 and ubiquitin-editing enzyme A20. Immunol. Cell Biol. 2012; 90: 640-54.

[66] D. Bosisio, N. Polentarutti, M. Sironi, S. Bernasconi, K. Miyake, G.R. Webb, M.U. Martin, A. Mantovani and M. Muzio. Stimulation of toll-like receptor 4 expression in human mononuclear phagocytes by interferon-gamma: a molecular basis for priming and synergism with bacterial lipopolysaccharide. Blood 2002; 99: 3427-31.

[67] J.A. Rettew, Y.M. Huet and I. Marriott. Estrogens augment cell surface TLR4 expression on murine macrophages and regulate sepsis susceptibility in vivo. Endocrinology 2009; 150: 3877-84. 
[68] J.A. Rettew, Y.M. Huet-Hudson and I. Marriott. Testosterone reduces macrophage expression in the mouse of toll-like receptor 4, a trigger for inflammation and innate immunity. Biol. Reprod. 2008; 78: 432-7.

[69] Q.Q. Huang, R. Sobkoviak, A.R. Jockheck-Clark, B. Shi, A.M. Mandelin, 2nd, P.P. Tak, G.K. Haines, 3rd, C.V. Nicchitta and R.M. Pope. Heat shock protein 96 is elevated in rheumatoid arthritis and activates macrophages primarily via TLR2 signaling. J. Immunol. 2009; 182: 4965-73.

[70] L.N. Schulte, A.J. Westermann and J. Vogel. Differential activation and functional specialization of miR-146 and miR-155 in innate immune sensing. Nucleic Acids Res. 2013; 41: 542-53.

[71] E.H. Noss and M.B. Brenner. The role and therapeutic implications of fibroblastlike synoviocytes in inflammation and cartilage erosion in rheumatoid arthritis. Immunol. Rev. 2008; 223: 252-70.

[72] Z. Szekanecz, T. Besenyei, G. Paragh and A.E. Koch. New insights in synovial angiogenesis. Joint Bone Spine 77: 13-9.

[73] B. Bartok and G.S. Firestein. Fibroblast-like synoviocytes: key effector cells in rheumatoid arthritis. Immunol. Rev. 2010; 233: 233-55.

[74] Y.O. Jung, M.L. Cho, C.M. Kang, J.Y. Jhun, J.S. Park, H.J. Oh, J.K. Min, S.H. Park and H.Y. Kim. Toll-like receptor 2 and 4 combination engagement upregulate IL-15 synergistically in human rheumatoid synovial fibroblasts. Immunol. Lett. 2007; 109: 21-7.

[75] L. Meng, W. Zhu, C. Jiang, X. He, W. Hou, F. Zheng, R. Holmdahl and S. Lu. Toll-like receptor 3 upregulation in macrophages participates in the initiation and 
maintenance of pristane-induced arthritis in rats. Arthritis Res. Ther. 2010; 12: R103.

[76] S.M. Sacre, E. Andreakos, S. Kiriakidis, P. Amjadi, A. Lundberg, G. Giddins, M. Feldmann, F. Brennan and B.M. Foxwell. The Toll-like receptor adaptor proteins MyD88 and Mal/TIRAP contribute to the inflammatory and destructive processes in a human model of rheumatoid arthritis. Am. J. Pathol. 2007; 170: 518-25.

[77] K.W. Kim, M.L. Cho, S.H. Lee, H.J. Oh, C.M. Kang, J.H. Ju, S.Y. Min, Y.G. Cho, S.H. Park and H.Y. Kim. Human rheumatoid synovial fibroblasts promote osteoclastogenic activity by activating RANKL via TLR-2 and TLR-4 activation. Immunol. Lett. 2007; 110: 54-64.

[78] S.Y. Lee, B.Y. Yoon, J.I. Kim, Y.M. Heo, Y.J. Woo, S.H. Park, H.Y. Kim, S.I. Kim and M.L. Cho. Interleukin-17 increases the expression of Toll-like receptor 3 via the STAT3 pathway in rheumatoid arthritis fibroblast-like synoviocytes. Immunology 2014; 141: 353-61.

[79] D. Kyburz, J. Rethage, R. Seibl, R. Lauener, R.E. Gay, D.A. Carson and S. Gay. Bacterial peptidoglycans but not $\mathrm{CpG}$ oligodeoxynucleotides activate synovial fibroblasts by toll-like receptor signaling. Arthritis Rheum. 2003; 48: 642-50.

[80] L. Xu, X. Feng, W. Tan, W. Gu, D. Guo, M. Zhang and F. Wang. IL-29 enhances Toll-like receptor-mediated IL-6 and IL-8 production by the synovial fibroblasts from rheumatoid arthritis patients. Arthritis Res. Ther. 2013; 15: R170.

[81] F. Brentano, D. Kyburz and S. Gay. Toll-like receptors and rheumatoid arthritis. Methods Mol. Biol. 2009; 517: 329-43. 
[82] E.M. Gravallese. Bone destruction in arthritis. Annals of the Rheumatic Diseases. 2002; 61 Suppl 2: ii84-6.

[83] G. Schett. Joint remodelling in inflammatory disease. Annals of the Rheumatic Diseases. 2007; 66 Suppl 3: iii42-4.

[84] N.C. Walsh and E.M. Gravallese. Bone loss in inflammatory arthritis: mechanisms and treatment strategies. Curr. Opin. Rheumatol. 2004; 16: 419-27.

[85] G. Schett and E. Gravallese. Bone erosion in rheumatoid arthritis: mechanisms, diagnosis and treatment. Nat. Rev. Rheumatol. 2012; 8: 656-64.

[86] J.D. Ji, K.H. Park-Min, Z. Shen, R.J. Fajardo, S.R. Goldring, K.P. McHugh and L.B. Ivashkiv. Inhibition of RANK expression and osteoclastogenesis by TLRs and IFN-gamma in human osteoclast precursors. J. Immunol. 2009; 183: 7223-33.

[87] M. Takami, N. Kim, J. Rho and Y. Choi. Stimulation by toll-like receptors inhibits osteoclast differentiation. J. Immunol. 2002; 169: 1516-23.

[88] A. Amcheslavsky and Z. Bar-Shavit. Interleukin (IL)-12 mediates the antiosteoclastogenic activity of CpG-oligodeoxynucleotides. J. Cell. Physiol. 2006; 207: 244-50.

[89] W.B. van den Berg, P.L. van Lent, L.A. Joosten, S. Abdollahi-Roodsaz and M.I. Koenders. Amplifying elements of arthritis and joint destruction. Ann. Rheum. Dis. 2007; 66 Suppl 3: iii45-8.

[90] S. Abdollahi-Roodsaz, L.A. Joosten, M.I. Koenders, B.T. van den Brand, F.A. van de Loo and W.B. van den Berg. Local interleukin-1-driven joint pathology is dependent on toll-like receptor 4 activation. Am. J. Pathol. 2009; 175: 2004-13. 
[91] A. Miyamoto, M. Takami, A. Matsumoto, A. Mochizuki, T. Yamada, K. Tachi, I. Shibuya, T. Nakamachi, S. Shioda, K. Baba, T. Inoue, Y. Miyamoto, M. Yim and R. Kamijo. R848, a toll-like receptor 7 agonist, inhibits osteoclast differentiation but not survival or bone-resorbing function of mature osteoclasts. Cytotechnology 2012; 64: 331-9.

[92] S. Shahrara, Q. Huang, A.M. Mandelin, 2nd and R.M. Pope. TH-17 cells in rheumatoid arthritis. Arthritis Res. Ther. 2008; 10: R93.

[93] M.V. Volin and S. Shahrara. Role of TH-17 cells in rheumatic and other autoimmune diseases. Rheumatology (Sunnyvale) 2011; 1.

[94] W.B. van den Berg and P. Miossec. IL-17 as a future therapeutic target for rheumatoid arthritis. Nat. Rev. Rheumatol. 2009; 5: 549-53.

[95] J. Pene, S. Chevalier, L. Preisser, E. Venereau, M.H. Guilleux, S. Ghannam, J.P. Moles, Y. Danger, E. Ravon, S. Lesaux, H. Yssel and H. Gascan. Chronically inflamed human tissues are infiltrated by highly differentiated Th17 lymphocytes. J. Immunol. 2008; 180: 7423-30.

[96] M. Noack and P. Miossec. Th17 and regulatory T cell balance in autoimmune and inflammatory diseases. Autoimmunity reviews 2014; 13: 668-77.

[97] M. Samson, S. Audia, N. Janikashvili, M. Ciudad, M. Trad, J. Fraszczak, P. Ornetti, J.F. Maillefert, P. Miossec and B. Bonnotte. Brief report: inhibition of interleukin-6 function corrects Th17/Treg cell imbalance in patients with rheumatoid arthritis. Arthritis Rheum. 2012; 64: 2499-503. 
[98] M.G. Kattah, M.T. Wong, M.D. Yocum and P.J. Utz. Cytokines secreted in response to Toll-like receptor ligand stimulation modulate differentiation of human Th17 cells. Arthritis Rheum. 2008; 58: 1619-29.

[99] T. Vogl, K. Tenbrock, S. Ludwig, N. Leukert, C. Ehrhardt, M.A. van Zoelen, W. Nacken, D. Foell, T. van der Poll, C. Sorg and J. Roth. Mrp8 and Mrp14 are endogenous activators of Toll-like receptor 4, promoting lethal, endotoxininduced shock. Nat. Med. 2007; 13: 1042-9.

[100] A. Baillet, C. Trocme, S. Berthier, M. Arlotto, L. Grange, J. Chenau, S. Quetant, M. Seve, F. Berger, R. Juvin, F. Morel and P. Gaudin. Synovial fluid proteomic fingerprint: S100A8, S100A9 and S100A12 proteins discriminate rheumatoid arthritis from other inflammatory joint diseases. Rheumatology (Oxford) 2010; 49: 671-82.

[101] D.G. Lee, J.W. Woo, S.K. Kwok, M.L. Cho and S.H. Park. MRP8 promotes Th17 differentiation via upregulation of IL-6 production by fibroblast-like synoviocytes in rheumatoid arthritis. Exp. Mol. Med. 2013; 45: e20.

[102] T. Adjobimey, J. Satoguina, J. Oldenburg, A. Hoerauf and L.E. Layland. Coactivation through TLR4 and TLR9 but not TLR2 skews Treg-mediated modulation of Igs and induces IL-17 secretion in Treg: B cell co-cultures. Innate Immun. 2014; 20: 12-23.

[103] R.P. Sutmuller, M.H. den Brok, M. Kramer, E.J. Bennink, L.W. Toonen, B.J. Kullberg, L.A. Joosten, S. Akira, M.G. Netea and G.J. Adema. Toll-like receptor 2 controls expansion and function of regulatory T cells. J. Clin. Invest. 2006; 116: $485-94$. 
[104] S. Abdollahi-Roodsaz, L.A. Joosten, M.I. Koenders, I. Devesa, M.F. Roelofs, T.R. Radstake, M. Heuvelmans-Jacobs, S. Akira, M.J. Nicklin, F. Ribeiro-Dias and W.B. van den Berg. Stimulation of TLR2 and TLR4 differentially skews the balance of $\mathrm{T}$ cells in a mouse model of arthritis. J. Clin. Invest. 2008; 118: 20516.

[105] T. Dzopalic, A. Dragicevic, S. Vasilijic, D. Vucevic, I. Majstorovic, B. Bozic, B. Balint and M. Colic. Loxoribine, a selective Toll-like receptor 7 agonist, induces maturation of human monocyte-derived dendritic cells and stimulates their Th-1and Th-17-polarizing capability. Int. Immunopharmacol. 2010; 10: 1428-33.

[106] C.K. Holm, C.C. Petersen, M. Hvid, L. Petersen, S.R. Paludan, B. Deleuran and M. Hokland. TLR3 ligand polyinosinic:polycytidylic acid induces IL-17A and IL21 synthesis in human Th cells. J. Immunol. 2009; 183: 4422-31.

[107] A.E. Koch. Angiogenesis: implications for rheumatoid arthritis. Arthritis Rheum. 1998; 41: 951-62.

[108] Z. Szekanecz and A.E. Koch. Angiogenesis and its targeting in rheumatoid arthritis. Vascul. Pharmacol. 2009; 51: 1-7.

[109] Z. Szekanecz, A. Pakozdi, A. Szentpetery, T. Besenyei and A.E. Koch. Chemokines and angiogenesis in rheumatoid arthritis. Front Biosci (Elite Ed) 2009; 1: 44-51.

[110] G. Pinhal-Enfield, M. Ramanathan, G. Hasko, S.N. Vogel, A.L. Salzman, G.J. Boons and S.J. Leibovich. An angiogenic switch in macrophages involving synergy between Toll-like receptors $2,4,7$, and 9 and adenosine $\mathrm{A}(2 \mathrm{~A})$ receptors. Am. J. Pathol. 2003; 163: 711-21. 
[111] Q. Lin, X.P. Yang, D. Fang, X. Ren, H. Zhou, J. Fang, X. Liu, S. Zhou, F. Wen, X. Yao, J.M. Wang and S.B. Su. High-mobility group box-1 mediates toll-like receptor 4-dependent angiogenesis. Arterioscler. Thromb. Vasc. Biol. 2011; 31: 1024-32.

[112] S.Y. Park, S.W. Lee, H.Y. Kim, W.S. Lee, K.W. Hong and C.D. Kim. HMGB1 induces angiogenesis in rheumatoid arthritis via HIF-1alpha activation. Eur. J. Immunol. 2015; 45: 1216-27.

[113] M.L. Cho, J.H. Ju, H.R. Kim, H.J. Oh, C.M. Kang, J.Y. Jhun, S.Y. Lee, M.K. Park, J.K. Min, S.H. Park, S.H. Lee and H.Y. Kim. Toll-like receptor 2 ligand mediates the upregulation of angiogenic factor, vascular endothelial growth factor and interleukin-8/CXCL8 in human rheumatoid synovial fibroblasts. Immunol. Lett. 2007; 108: 121-8.

[114] T. Saber, D.J. Veale, E. Balogh, J. McCormick, S. NicAnUltaigh, M. Connolly and U. Fearon. Toll-like receptor 2 induced angiogenesis and invasion is mediated through the Tie2 signalling pathway in rheumatoid arthritis. PLoS One 2011;6: e23540.

[115] S. Murad. Toll-like receptor 4 in inflammation and angiogenesis: a double-edged sword. Front. Immunol. 2014; 5: 313.

[116] L.A. Joosten, M.I. Koenders, R.L. Smeets, M. Heuvelmans-Jacobs, M.M. Helsen, K. Takeda, S. Akira, E. Lubberts, F.A. van de Loo and W.B. van den Berg. Tolllike receptor 2 pathway drives streptococcal cell wall-induced joint inflammation: critical role of myeloid differentiation factor 88. J. Immunol. 2003; 171: 6145-53. 
[117] S. Abdollahi-Roodsaz, L.A. Joosten, M.M. Helsen, B. Walgreen, P.L. van Lent, L.A. van den Bersselaar, M.I. Koenders and W.B. van den Berg. Shift from tolllike receptor 2 (TLR-2) toward TLR-4 dependency in the erosive stage of chronic streptococcal cell wall arthritis coincident with TLR-4-mediated interleukin-17 production. Arthritis Rheum. 2008; 58: 3753-64.

[118] S. Abdollahi-Roodsaz, L.A. Joosten, M.F. Roelofs, T.R. Radstake, G. Matera, C. Popa, J.W. van der Meer, M.G. Netea and W.B. van den Berg. Inhibition of Tolllike receptor 4 breaks the inflammatory loop in autoimmune destructive arthritis. Arthritis Rheum. 2007; 56: 2957-67.

[119] J.Y. Choe, B. Crain, S.R. Wu and M. Corr. Interleukin 1 receptor dependence of serum transferred arthritis can be circumvented by toll-like receptor 4 signaling. J. Exp. Med. 2003; 197: 537-42.

[120] F. Zare, M. Bokarewa, N. Nenonen, T. Bergstrom, L. Alexopoulou, R.A. Flavell and A. Tarkowski. Arthritogenic properties of double-stranded (viral) RNA. J. Immunol. 2004; 172: 5656-63.

[121] P. Duffau, H. Menn-Josephy, C.M. Cuda, S. Dominguez, T.R. Aprahamian, A.A. Watkins, K. Yasuda, P. Monach, R. Lafyatis, L.M. Rice, G. Kenneth Haines, 3rd, E.M. Gravallese, R. Baum, C. Richez, H. Perlman, R.G. Bonegio and I.R. Rifkin. Promotion of Inflammatory Arthritis by Interferon Regulatory Factor 5 in a Mouse Model. Arthritis Rheumatol 2015; 67: 3146-57.

[122] A. Yarilina, E. DiCarlo and L.B. Ivashkiv. Suppression of the effector phase of inflammatory arthritis by double-stranded RNA is mediated by type I IFNs. J. Immunol. 2007; 178: 2204-11. 
[123] H.J. Wu, H. Sawaya, B. Binstadt, M. Brickelmaier, A. Blasius, L. Gorelik, U. Mahmood, R. Weissleder, J. Carulli, C. Benoist and D. Mathis. Inflammatory arthritis can be reined in by CpG-induced DC-NK cell cross talk. J. Exp. Med. 2007; 204: 1911-22.

[124] S.Y. Chen, A.L. Shiau, Y.T. Li, Y.S. Lin, C.H. Lee, C.L. Wu and C.R. Wang. Suppression of collagen-induced arthritis by intra-articular lentiviral vectormediated delivery of Toll-like receptor 7 short hairpin RNA gene. Gene Ther. 2012; 19: 752-60.

[125] S. Alzabin, P. Kong, M. Medghalchi, A. Palfreeman, R. Williams and S. Sacre. Investigation of the role of endosomal Toll-like receptors in murine collageninduced arthritis reveals a potential role for TLR7 in disease maintenance. Arthritis Res. Ther. 2012; 14: R142.

[126] E.J. Hennessy, A.E. Parker and L.A. O'Neill. Targeting Toll-like receptors: emerging therapeutics? Nature reviews. Drug discovery 2010; 9: 293-307.

[127] B. Keogh and A.E. Parker. Toll-like receptors as targets for immune disorders. Trends Pharmacol. Sci. 2011; 32: 435-42.

[128] M. Reilly, R.M. Miller, M.H. Thomson, V. Patris, P. Ryle, L. McLoughlin, P. Mutch, P. Gilboy, C. Miller, M. Broekema, B. Keogh, W. McCormack and J. van de Wetering de Rooij. Randomized, double-blind, placebo-controlled, doseescalating phase I, healthy subjects study of intravenous OPN-305, a humanized anti-TLR2 antibody. Clin. Pharmacol. Ther. 2013; 94: 593-600.

[129] S.N. Ultaigh, T.P. Saber, J. McCormick, M. Connolly, J. Dellacasagrande, B. Keogh, W. McCormack, M. Reilly, L.A. O'Neill, P. McGuirk, U. Fearon and D.J. 
Veale. Blockade of Toll-like receptor 2 prevents spontaneous cytokine release from rheumatoid arthritis ex vivo synovial explant cultures. Arthritis Res. Ther. 2011; 13: R33.

[130] E. Czeslick, A. Struppert, A. Simm and A. Sablotzki. E5564 (Eritoran) inhibits lipopolysaccharide-induced cytokine production in human blood monocytes. Inflamm. Res. 2006; 55: 511-5.

[131] I. Ben-Zvi, S. Kivity, P. Langevitz and Y. Shoenfeld. Hydroxychloroquine: from malaria to autoimmunity. Clin. Rev. Allergy Immunol. 2012; 42: 145-53.

[132] S. Sacre, M. Medghalchi, B. Gregory, F. Brennan and R. Williams. Fluoxetine and citalopram exhibit potent antiinflammatory activity in human and murine models of rheumatoid arthritis and inhibit toll-like receptors. Arthritis Rheum. 2010; 62: 683-93.

[133] H. Schierbeck, P. Lundback, K. Palmblad, L. Klevenvall, H. Erlandsson-Harris, U. Andersson and L. Ottosson. Monoclonal anti-HMGB1 (high mobility group box chromosomal protein 1) antibody protection in two experimental arthritis models. Mol. Med. 2011; 17: 1039-44.

[134] R. Kokkola, J. Li, E. Sundberg, A.C. Aveberger, K. Palmblad, H. Yang, K.J. Tracey, U. Andersson and H.E. Harris. Successful treatment of collagen-induced arthritis in mice and rats by targeting extracellular high mobility group box chromosomal protein 1 activity. Arthritis Rheum. 2003; 48: 2052-8.

[135] L.A. O'Neill, F.J. Sheedy and C.E. McCoy. MicroRNAs: the fine-tuners of Tolllike receptor signalling. Nat. Rev. Immunol. 2011;11: 163-75. 
[136] M.A. Nahid, M. Satoh and E.K. Chan. Mechanistic role of microRNA-146a in endotoxin-induced differential cross-regulation of TLR signaling. J. Immunol. 2011; 186: 1723-34.

[137] S.B. Cohen, T.T. Cheng, V. Chindalore, N. Damjanov, R. Burgos-Vargas, P. Delora, K. Zimany, H. Travers and J.P. Caulfield. Evaluation of the efficacy and safety of pamapimod, a p38 MAP kinase inhibitor, in a double-blind, methotrexate-controlled study of patients with active rheumatoid arthritis. Arthritis Rheum. 2009; 60: 335-44.

[138] R.E. Alten, C. Zerbini, S. Jeka, F. Irazoque, F. Khatib, P. Emery, A. Bertasso, M. Rabbia and J.P. Caulfield. Efficacy and safety of pamapimod in patients with active rheumatoid arthritis receiving stable methotrexate therapy. Ann. Rheum. Dis. 2010; 69: 364-7.

[139] S. Iyer, D. Kontoyiannis, D. Chevrier, J. Woo, N. Mori, M. Cornejo, G. Kollias and R. Buelow. Inhibition of tumor necrosis factor mRNA translation by a rationally designed immunomodulatory peptide. J. Biol. Chem. 2000; 275: 170517.

[140] W. Liu, B.R. Deyoung, X. Chen, D.P. Evanoff and Y. Luo. RDP58 inhibits T cell-mediated bladder inflammation in an autoimmune cystitis model. J. Autoimmun. 2008; 30: 257-65.

[141] A.G. Suryaprasad and T. Prindiville. The biology of TNF blockade. Autoimmunity reviews 2003; 2: 346-57.

[142] N.E. Aerts, K.J. De Knop, J. Leysen, D.G. Ebo, C.H. Bridts, J.J. Weyler, W.J. Stevens and L.S. De Clerck. Increased IL-17 production by peripheral T helper 
cells after tumour necrosis factor blockade in rheumatoid arthritis is accompanied by inhibition of migration-associated chemokine receptor expression. Rheumatology (Oxford) 2010; 49: 2264-72.

[143] S. Alzabin, S.M. Abraham, T.E. Taher, A. Palfreeman, D. Hull, K. McNamee, A. Jawad, E. Pathan, A. Kinderlerer, P.C. Taylor, R. Williams and R. Mageed. Incomplete response of inflammatory arthritis to TNFalpha blockade is associated with the Th17 pathway. Annals of the Rheumatic Diseases. 2012; 71: 1741-8. 


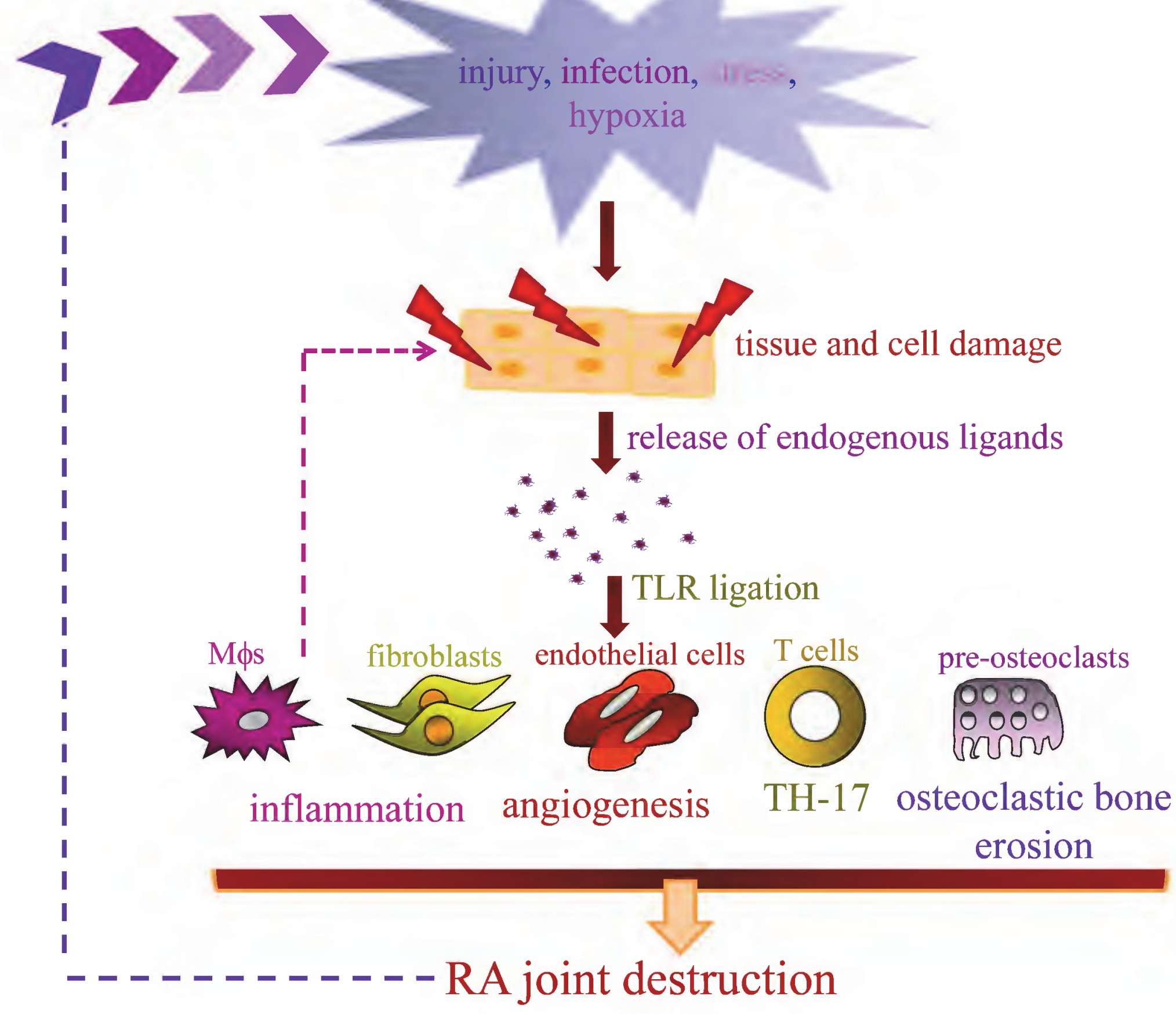


Figure 2

Cell death

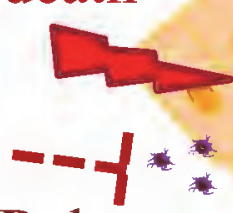

2. Release of

Triacyl Zymosan

LPS lipopeptides

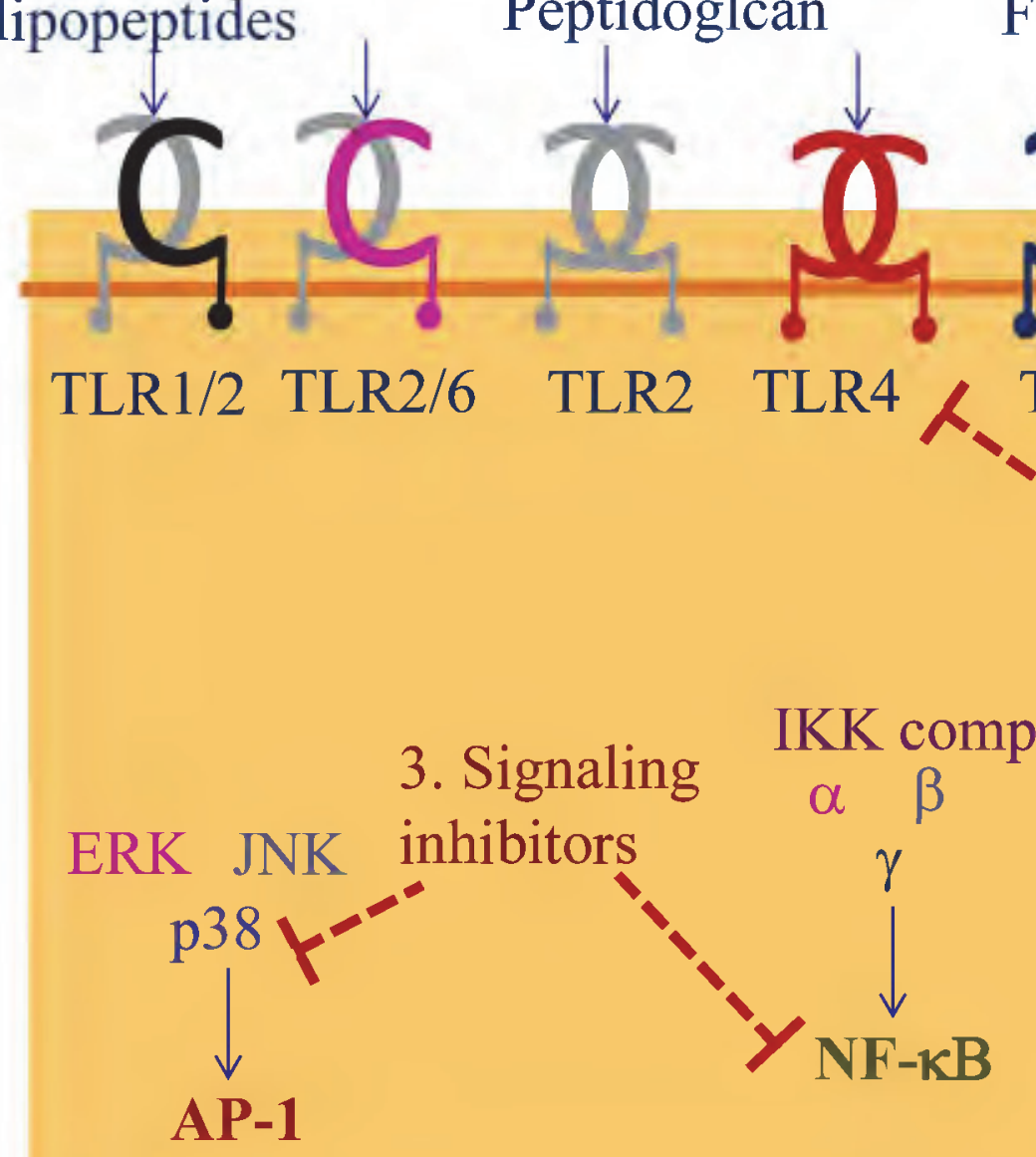

Flagellin

endogenous ligands

1. Ligand/receptor interaction

10 --- Abs and small molecule antagonists

TLR5

cell membrane

4. Receptor expression

(mi-RNAs)

3. Signaling IKK complex

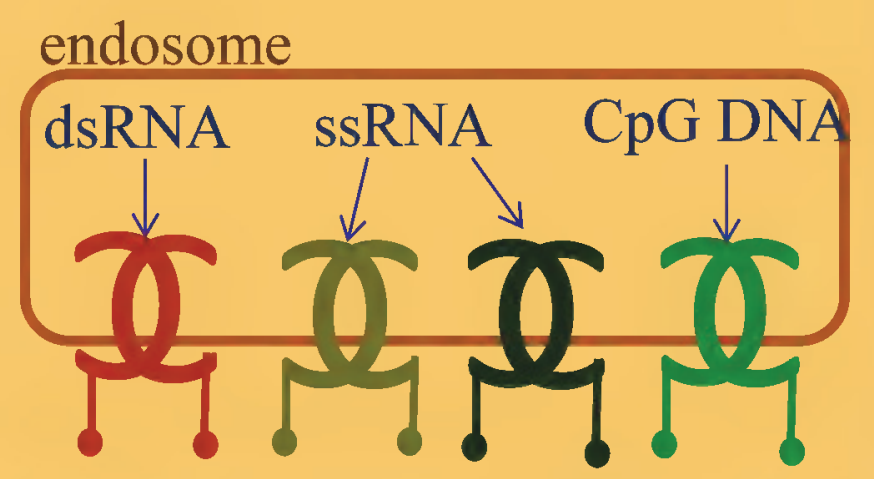

TLR3 TLR7 hTLR8 TLR9 
Figure 3

RA myeloid cells

RA mature osteoclasts Joint destruction

LPS

Flagellin miR-Let7b

$\Rightarrow$
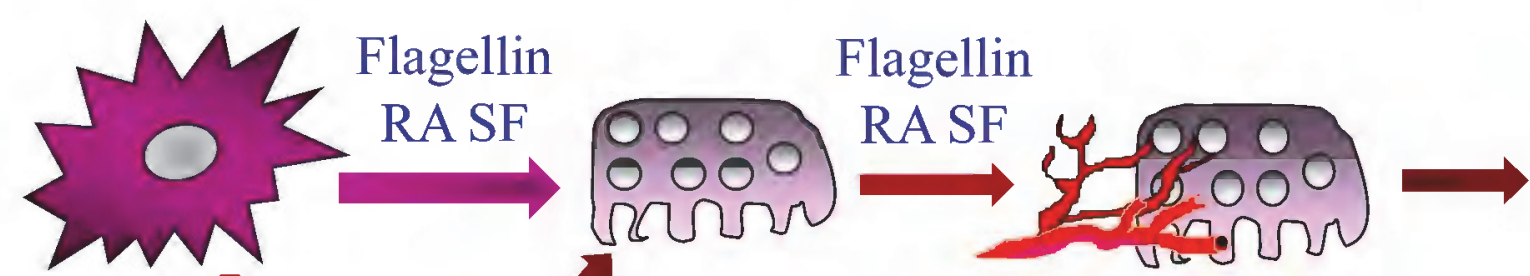

RA ST fibroblasts
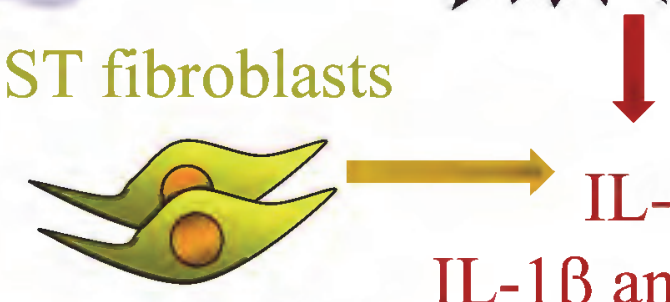

IL-6

IL- $1 \beta$ and TNF

Naïve T cells

TH-17 cells
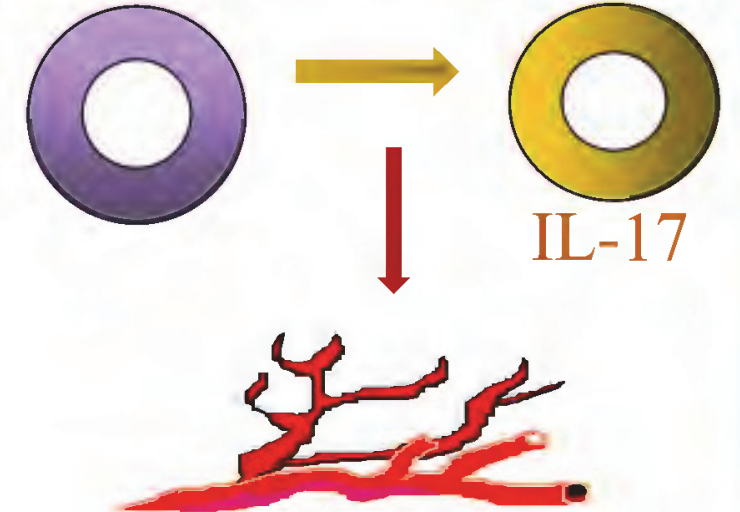

RA induced Angiogenesis
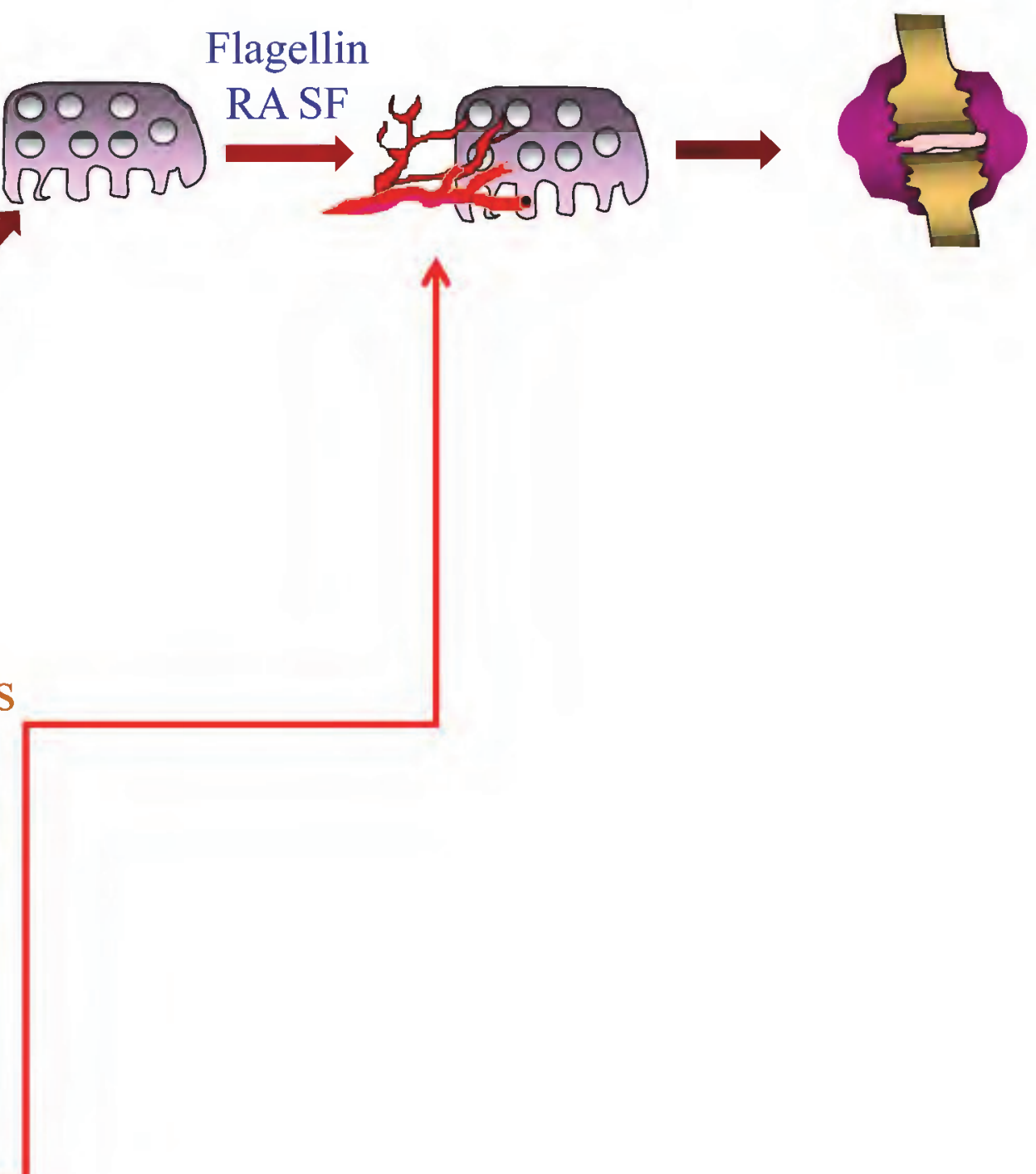